\title{
Low levels of nitryl chloride at ground level: nocturnal nitrogen oxides in the Lower Fraser Valley of British Columbia
}

\author{
Hans D. Osthoff ${ }^{1}$, Charles A. Odame-Ankrah ${ }^{1}$, Youssef M. Taha ${ }^{1}$, Travis W. Tokarek ${ }^{1}$, Corinne L. Schiller ${ }^{2}$, \\ Donna Haga $^{3}$, Keith Jones ${ }^{2}$, and Roxanne Vingarzan ${ }^{2}$ \\ ${ }^{1}$ Department of Chemistry, University of Calgary, Calgary, Alberta T2N 1N4, Canada \\ ${ }^{2}$ Applied Science Division, Prediction and Services West, Meteorological Service of Canada, Environment and Climate \\ Change Canada, Vancouver, British Columbia V6C 3S5, Canada \\ ${ }^{3}$ British Columbia Ministry of Environment and Climate Change Strategy, Cranbrook, British Columbia V1C 7G5, Canada
}

Correspondence: Hans D. Osthoff (hosthoff@ucalgary.ca)

Received: 2 November 2017 - Discussion started: 22 December 2017

Revised: 9 April 2018 - Accepted: 11 April 2018 - Published: 4 May 2018

\begin{abstract}
The nocturnal nitrogen oxides, which include the nitrate radical $\left(\mathrm{NO}_{3}\right)$, dinitrogen pentoxide $\left(\mathrm{N}_{2} \mathrm{O}_{5}\right)$, and its uptake product on chloride containing aerosol, nitryl chloride $\left(\mathrm{ClNO}_{2}\right)$, can have profound impacts on the lifetime of $\mathrm{NO}_{x}$ $\left(=\mathrm{NO}+\mathrm{NO}_{2}\right)$, radical budgets, and next-day photochemical ozone $\left(\mathrm{O}_{3}\right)$ production, yet their abundances and chemistry are only sparsely constrained by ambient air measurements.

Here, we present a measurement data set collected at a routine monitoring site near the Abbotsford International Airport (YXX) located approximately $30 \mathrm{~km}$ from the Pacific Ocean in the Lower Fraser Valley (LFV) on the west coast of British Columbia. Measurements were made from 20 July to 4 August 2012 and included mixing ratios of $\mathrm{ClNO}_{2}, \mathrm{~N}_{2} \mathrm{O}_{5}$, $\mathrm{NO}, \mathrm{NO}_{2}$, total odd nitrogen $\left(\mathrm{NO}_{y}\right), \mathrm{O}_{3}$, photolysis frequencies, and size distribution and composition of non-refractory submicron aerosol $\left(\mathrm{PM}_{1}\right)$.

At night, $\mathrm{O}_{3}$ was rapidly and often completely removed by dry deposition and by titration with $\mathrm{NO}$ of anthropogenic origin and unsaturated biogenic hydrocarbons in a shallow nocturnal inversion surface layer. The low nocturnal $\mathrm{O}_{3}$ mixing ratios and presence of strong chemical sinks for $\mathrm{NO}_{3}$ limited the extent of nocturnal nitrogen oxide chemistry at ground level. Consequently, mixing ratios of $\mathrm{N}_{2} \mathrm{O}_{5}$ and $\mathrm{ClNO}_{2}$ were low ( $<30$ and $<100$ parts-per-trillion by volume (pptv) and median nocturnal peak values of 7.8 and $7.9 \mathrm{pptv}$, respectively). Mixing ratios of $\mathrm{ClNO}_{2}$ frequently peaked $1-2 \mathrm{~h}$ after sunrise rationalized by more efficient formation of $\mathrm{ClNO}_{2}$ in the nocturnal residual layer aloft than at the surface and the breakup of the nocturnal boundary layer structure in
\end{abstract}

the morning. When quantifiable, production of $\mathrm{ClNO}_{2}$ from $\mathrm{N}_{2} \mathrm{O}_{5}$ was efficient and likely occurred predominantly on unquantified supermicron-sized or refractory sea-salt-derived aerosol. After sunrise, production of $\mathrm{Cl}$ radicals from photolysis of $\mathrm{ClNO}_{2}$ was negligible compared to production of $\mathrm{OH}$ from the reaction of $\mathrm{O}\left({ }^{1} \mathrm{D}\right)+\mathrm{H}_{2} \mathrm{O}$ except for a short period after sunrise.

\section{Introduction}

The Lower Fraser Valley (LFV) is prone to episodes of poor air quality, in part because of its geography, which facilitates stagnation periods and accumulation of airborne pollutants through processes such as the Wake-Induced Stagnation Effect (Brook et al., 2004), and also because of continued growth of human population and associated emissions from urban, suburban, agricultural, and marine sources. Of special concern have been repeated exceedances of the Canada-wide standard and, as of 2012, the Canadian Ambient Air Quality Standards (CAAQS) for fine particulate matter $\left(\mathrm{PM}_{2.5}\right)$ and ozone $\left(\mathrm{O}_{3}\right)$ at Chilliwack and Hope, located in the eastern part of the LFV downwind of Vancouver (Ainslie et al., 2013). These exceedances have occurred in spite of ongoing declines in emissions of both nitrogen oxides $\left(\mathrm{NO}_{x}=\mathrm{NO}+\mathrm{NO}_{2}\right)$ and volatile organic compounds (VOCs) resulting from the introduction of new vehicle standards and (now discontinued) local vehicle emission testing programs (Ainslie et al., 2013). Previous large-scale studies 
in the LFV such as Pacific 1993 (Steyn et al., 1997), the Regional Visibility Experimental Assessment in the Lower Fraser Valley (REVEAL) I and II (Pryor et al., 1997; Pryor and Barthelmie, 2000), and Pacific 2001 (Vingarzan and $\mathrm{Li}, 2006)$ have added important information regarding atmospheric processes, leading to $\mathrm{O}_{3}$ and aerosol formation and visibility issues. However, the transformation of primary (e.g., $\mathrm{NO}_{x}, \mathrm{VOCs}, \mathrm{SO}_{2}, \mathrm{NH}_{3}$ ) to secondary pollutants (i.e., $\mathrm{O}_{3}$ and fine particulate matter) is highly complex, and the scientific understanding of these highly non-linear processes remains incomplete.

A complicating factor in the LFV is the interaction of anthropogenic emissions with marine-derived sea salt aerosol. While sea spray aerosol is a primary source of particulate matter (PM) and hence directly affects particle concentrations and mass loadings (Pryor et al., 2008) and aerosol chloride concentrations (Anlauf et al., 2006) in the LFV, there is now considerable evidence from modelling (Knipping and Dabdub, 2003), laboratory (Raff et al., 2009), and field studies (Tanaka et al., 2003; Osthoff et al., 2008) that "active chlorine" species released from sea salt can negatively affect air quality and promote $\mathrm{O}_{3}$ and secondary aerosol formation in coastal regions.

In an analysis of 20 years of $\mathrm{O}_{3}$ air quality data in the LFV region, Ainslie and Steyn (2007) concluded that precursor buildup, prior to an exceedance day, plays an important role in the spatial $\mathrm{O}_{3}$ pattern on exceedance days. Secondary processes involving active chlorine produced from the interaction of marine aerosol with anthropogenic pollution would fit this profile but are not currently constrained by measurements.

One pathway to activate chlorine from sea salt is the reactive uptake of dinitrogen pentoxide $\left(\mathrm{N}_{2} \mathrm{O}_{5}\right)$ on chloride containing aerosol to yield nitryl chloride $\left(\mathrm{ClNO}_{2}\right)($ Behnke et al., 1997; Finlayson-Pitts et al., 1989). Briefly, $\mathrm{N}_{2} \mathrm{O}_{5}$ is formed from the reversible reaction of nitrogen dioxide $\left(\mathrm{NO}_{2}\right)$ with the photolabile nitrate radical $\left(\mathrm{NO}_{3}\right.$; Reaction $\mathrm{R} 1$ ), which in turn is formed from reaction of $\mathrm{NO}_{2}$ with $\mathrm{O}_{3}$ (Reaction R2).

$\mathrm{NO}_{2}+\mathrm{O}_{3} \rightarrow \mathrm{NO}_{3}+\mathrm{O}_{2}$

$\mathrm{NO}_{3}+\mathrm{NO}_{2} \rightleftharpoons \mathrm{N}_{2} \mathrm{O}_{5}$

In ambient air, $\mathrm{N}_{2} \mathrm{O}_{5}, \mathrm{NO}_{3}$, and $\mathrm{NO}_{2}$ are usually in equilibrium; the equilibrium constant, $\mathrm{K}_{2}$, is temperature dependent, favouring $\mathrm{NO}_{3}$ and $\mathrm{NO}_{2}$ at higher temperatures (Osthoff et al., 2007). During daytime, $\mathrm{NO}_{3}$ (and, indirectly, $\mathrm{N}_{2} \mathrm{O}_{5}$ ) is removed primarily via its Reaction (R3) with $\mathrm{NO}$ (which is generated from $\mathrm{NO}_{2}$ photolysis and directly emitted, for example, by automobiles) and by $\mathrm{NO}_{3}$ photolysis (Reaction R4) (Wayne et al., 1991).
$\mathrm{NO}_{3}+\mathrm{NO} \rightarrow 2 \mathrm{NO}_{2}$

$\mathrm{NO}_{3}+h v \rightarrow 0.9 \mathrm{NO}_{2}+0.1 \mathrm{NO}$

The heterogeneous hydrolysis of $\mathrm{N}_{2} \mathrm{O}_{5}$ to nitric acid $\left(\mathrm{HNO}_{3}\right)$ is an important nocturnal $\mathrm{NO}_{x}$ and odd oxygen $\left(\mathrm{O}_{x}=\mathrm{NO}_{2}+\mathrm{O}_{3}\right)$ removal pathway (Chang et al., 2011; Brown et al., 2006a). On chloride containing aerosol, however, uptake of $\mathrm{N}_{2} \mathrm{O}_{5}$ yields up to a stoichiometric amount of $\mathrm{ClNO}_{2}$ (Reaction R5) (Behnke et al., 1997; Finlayson-Pitts et al., 1989):

$\mathrm{N}_{2} \mathrm{O}_{5}+\mathrm{H}_{2} \mathrm{O}$ (het) $+\varphi \mathrm{Cl}^{-}$(het) $\rightarrow(2-\varphi)$

$\mathrm{HNO}_{3}$ (het) $+\varphi \mathrm{ClNO}_{2}, 0 \leq \varphi \leq 1$.

The $\mathrm{ClNO}_{2}$ yield, $\varphi$, is primarily a function of aerosol chloride and water content (Behnke et al., 1997; Bertram and Thornton, 2009; Roberts et al., 2009; Ryder et al., 2014, 2015). Formation of $\mathrm{ClNO}_{2}$ impacts air quality in the following ways: since $\mathrm{ClNO}_{2}$ is long-lived at night, its primary fate is photodissociation (to $\mathrm{Cl}$ and $\mathrm{NO}_{2}$ ) in the morning hours after sunrise (Reaction R6) (Osthoff et al., 2008).

$\mathrm{ClNO}_{2}+h v \rightarrow \mathrm{NO}_{2}+\mathrm{Cl}$

This reaction increases the morning abundance of $\mathrm{O}_{x}$, leading to greater net photochemical $\mathrm{O}_{3}$ production throughout the day. The other photo-fragment, the $\mathrm{Cl}$ atom, is highly reactive towards hydrocarbons and will initiate radical chain reactions that produce $\mathrm{O}_{3}$ and secondary aerosol (Behnke et al., 1997; Young et al., 2014). The fate and impact of $\mathrm{ClNO}_{2}$ is thus similar to that of nitrous acid (HONO), which also accumulates during the night and photodissociates in the morning to release $\mathrm{NO}$ and the hydroxyl radical $(\mathrm{OH})$ that go on to produce $\mathrm{O}_{3}$ (Alicke et al., 2003).

Data collected during the 2006 Texas Air Quality Study - Gulf of Mexico Atmospheric Composition and Climate Study (TEXAQS-GOMACCS) have shown that $\mathrm{ClNO}_{2}$ production is efficient in the nocturnal polluted marine boundary layer even on primarily non-sea-salt aerosol surfaces (Osthoff et al., 2008). As a result, up to $15 \%$ of total odd nitrogen $\left(\mathrm{NO}_{y}\right)$ was present in the form $\mathrm{ClNO}_{2}$ at night (Osthoff et al., 2008). The high efficiency of $\mathrm{ClNO}_{2}$ formation on aerosol of medium-to-low total chloride content has been confirmed by several laboratory investigations (Bertram and Thornton, 2009; Raff et al., 2009; Roberts et al., 2009) and direct measurements of $\mathrm{N}_{2} \mathrm{O}_{5}$ uptake on ambient particles (Riedel et al., 2012b). Some ambiguity remains as to the detailed mechanism of Reaction (R5), but there is agreement that acid displacement of $\mathrm{HCl}$ from supermicron (predominantly sea salt aerosol) to submicron (predominantly nonsea-salt aerosol) is a key step in the efficient production of $\mathrm{ClNO}_{2}$. These results suggested that this chemistry is active anywhere that pollution in the form of $\mathrm{NO}_{x}$ and $\mathrm{O}_{3}$ comes in contact with marine air, including the LFV.

However, while the yield of $\mathrm{ClNO}_{2}$ in Reaction (R5) is high in polluted coastal regions, the $\mathrm{ClNO}_{2}$ yield relative to 
the amount of $\mathrm{NO}_{3}$ produced via Reaction (R1) cannot be easily predicted because $\mathrm{NO}_{3}$ is consumed by reactions with VOCs (Reaction R7), e.g., with biogenic VOCs such as isoprene and monoterpenes as well as aldehydes, and dimethyl sulfide (Wayne et al., 1991).

$\mathrm{NO}_{3}+\mathrm{VOC} \rightarrow$ products

Previous studies in the LFV have shown high biogenic VOC concentrations (Biesenthal et al., 1997; Gurren et al., 1998; Drewitt et al., 1998) yet there was active nighttime nitrogen oxide chemistry and aerosol chloride present mainly as seasalt-derived aerosol in $>1 \mu \mathrm{m}$ diameter aerosol (Anlauf et al., 2006). During the Pacific 2001 study, measurements of the mixing ratios of $\mathrm{NO}, \mathrm{NO}_{2}$, peroxyacetic nitric anhydride $\left(\mathrm{CH}_{3} \mathrm{C}(\mathrm{O}) \mathrm{O}_{2} \mathrm{NO}_{2}, \mathrm{PAN}\right), \mathrm{HONO}, \mathrm{HNO}_{3}$, and $\mathrm{NO}_{y}$ at three ground sites in the LFV indicated deficits of up to $15 \%$ in the nocturnal $\mathrm{NO}_{y}$ budget (Hayden et al., 2004) attributable to unquantified species such as alkyl nitrates, $\mathrm{N}_{2} \mathrm{O}_{5}$, and $\mathrm{ClNO}_{2}$. McLaren and coworkers quantified mixing ratios of $\mathrm{NO}_{2}$ and $\mathrm{NO}_{3}$ by differential optical absorption spectroscopy $(\mathrm{DOAS})$ at the Sumas Eagle Ridge site $(\sim 250 \mathrm{~m}$ above the floor of the LFV) as part of Pacific 2001 (McLaren et al., 2004) and off-shore on Saturna Island (Fig. 1) in the Strait of Georgia in 2005 (McLaren et al., 2010). The LFV data showed occasional episodes of active nocturnal nitrogen oxide chemistry in the residual layer with $\mathrm{N}_{2} \mathrm{O}_{5}$ contributing up to $9 \%$ of $\mathrm{NO}_{y}$, while the Saturna Island data showed $\mathrm{NO}_{3}$ mixing ratios of $>20$ parts-per-trillion by volume $\left(10^{-12} \mathrm{pptv}\right)$ every night of measurement. McLaren et al. (2010) estimated that between 0.3 and 1.9 ppbv of $\mathrm{ClNO}_{2}$ would be produced under these conditions. Efficient formation of $\mathrm{ClNO}_{2}$ would be consistent with the unidentified $\mathrm{O}_{3}$ precursor proposed by Ainslie and Steyn and is also a plausible explanation for part of the deficit in the $\mathrm{NO}_{y}$ budget observed by Hayden et al. (2004).

Another feature of the LFV are somewhat unusual diurnal profiles arising from the vertical structure in pollutant concentrations. Measurements of $\mathrm{O}_{3}$ and $\mathrm{NO}_{2}$ using tethered balloons by Pisano et al. (1997) during Pacific 93 at the Harris Road site (located $\sim 38 \mathrm{~km} \mathrm{NW}$ of Abbotsford International Airport) revealed a highly stratified boundary layer with a shallow, $50 \mathrm{~m}$ deep isothermal surface layer (also called a nocturnal boundary layer, or NBL) and low surface $\mathrm{O}_{3}$ concentrations at night. Nocturnal loss of surface $\mathrm{O}_{3}$ is known to occur by several pathways, including dry deposition, titration with NO (Reaction R8), and reaction with unsaturated biogenic hydrocarbons (Neu et al., 1994; Kleinman et al., 1994; Trainer et al., 1987; Logan, 1989; Talbot et al., 2005). Titration of $\mathrm{O}_{3}$ with $\mathrm{NO}$ is readily quantified as the concentration of a product of Reaction ( $\mathrm{R} 8), \mathrm{NO}_{2}$, can be measured directly and conserves $\mathrm{O}_{x}$.

$\mathrm{O}_{3}+\mathrm{NO} \rightarrow \mathrm{O}_{2}+\mathrm{NO}_{2}$

Usually, the major nocturnal sink of $\mathrm{O}_{x}$ is dry deposition of $\mathrm{O}_{3}$ and $\mathrm{NO}_{2}$ (Lin et al., 2010).

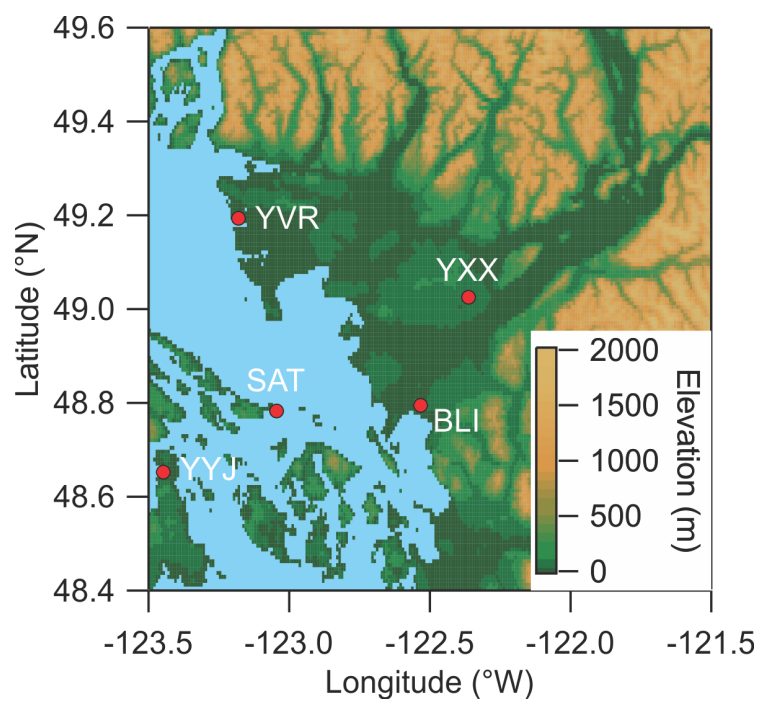

Figure 1. Map of the Lower Fraser Valley. YXX is the Abbotsford International Airport (measurement location for this study). YVR is the Vancouver International Airport. YYJ is the Victoria International Airport. BLI is the Bellingham International Airport. SAT is Saturna Island.

The balloon data also showed pools of $\mathrm{NO}_{2}$ and $\mathrm{O}_{3}$ in a $\sim 100 \mathrm{~m}$ deep nocturnal residual layer (NRL) located 200 to $350 \mathrm{~m}$ above ground. Following the breakup of the nocturnal layers in the early morning, vertical down-mixing events of $\mathrm{O}_{3}$ pollution were observed (McKendry et al., 1997). In this process, pollutants are entrained into the growing mixed layer from the NRL, i.e., the growing mixed layer in the hours after sunrise erodes the somewhat deeper NRL, and pollutants are mixed to the surface (Neu et al., 1994; Kleinman et al., 1994).

In this paper, we present the first measurements of $\mathrm{ClNO}_{2}$ and $\mathrm{N}_{2} \mathrm{O}_{5}$ mixing ratios in the LFV. The data were collected at a surface site east of the Abbotsford International Airport (International Air Transport Association (IATA) airport code YXX) located approximately $35 \mathrm{~km}$ from the Pacific Ocean from 20 July to 5 August, 2012. Auxiliary measurements included $\mathrm{NO}, \mathrm{NO}_{2}, \mathrm{NO}_{y}, \mathrm{O}_{3}$, photolysis frequencies, and nonrefractory $\mathrm{PM}_{1}$ aerosol composition and size distributions. An analysis of nocturnal nitrogen oxide chemistry including the formation of $\mathrm{ClNO}_{2}$ and its potential impact on nocturnal $\mathrm{O}_{3}$ and $\mathrm{NO}_{2}$ loss and radical budgets in the LFV are presented.

\section{Experimental}

\subsection{Location}

The map shown in Fig. 1 indicates the location of the study. Ambient air measurements were conducted at the T45 routine monitoring site located to the east YXX at latitude $49.0212(\mathrm{~N})$ and longitude $-122.3267(\mathrm{~W})$ and $\sim 60 \mathrm{~m}$ 
above sea level (a.s.l.) and $\sim 30 \mathrm{~km}$ from the Pacific Ocean. A raspberry field was located immediately to the $\mathrm{W}$ between the end of the airport runway and the measurement site. Nearby local sources included agricultural operations (such as poultry farms) and emissions from motor vehicle traffic on secondary roads and highways. YXX is located $\sim 60 \mathrm{~km} \mathrm{ESE}$ of the Vancouver International Airport (YVR) and the City of Vancouver. Abbotsford is in the heart of the so-called "lower mainland", the low-lying region stretching from the Pacific Ocean at Vancouver to the NW and the Canada-USA border to the S (north of Bellingham, BLI) to the eastern end of the Fraser Valley, with a total population in excess of 2500000.

\subsection{Measurement techniques}

The measurement techniques used for this study are listed in Table 1. Data were averaged to $5 \mathrm{~min}$ prior to presentation.

The instruments measuring $\mathrm{O}_{3}$ and nitrogen oxides were housed in an air-conditioned trailer and sampled from a common $0.635 \mathrm{~cm}(1 / 4 \mathrm{in}$.) outer diameter (OD) and $0.476 \mathrm{~cm}$ (3/16 in.) inner diameter (ID) Teflon ${ }^{\mathrm{TM}}$ inlet at a height of $4 \mathrm{~m}$ above ground; the setup is depicted in Fig. 3 of Tokarek et al. (2014). A scroll pump whose flow rate was throttled using a 50 standard litres per minute (slpm) capacity mass flow controller was connected to the end of the common inlet to minimize the residence time of the sampled air and to reduce inlet "aging", i.e., accumulation of aerosol on filters of individual instruments, whose inlets tapped into the main inlet line at $90^{\circ}$. The total inlet flow was in the range of 18 to 20 slpm.

Measurements of $\mathrm{PM}_{1}$ aerosol composition and size distributions (Sect. 2.3) and of meteorological data were made from the research trailer housing the routine measurements at the site. The Agilent VOC measurements were made from a research trailer owned by Environment and Climate Change Canada (ECCC).

\subsubsection{Quantification of $\mathrm{ClNO}_{2}$ by iodide chemical ionization mass spectrometry}

Mixing ratios of $\mathrm{ClNO}_{2}$ were quantified as iodide cluster ions at $m / z 208$ using the THS Instruments iodide chemical ionization mass spectrometer (iCIMS) described by Mielke et al. (2011) and calibrated using the scheme by Thaler et al. (2011). In this method, a gas stream containing $\mathrm{ClNO}_{2}$ is generated from reaction of $\mathrm{Cl}_{2}$ (Praxair, $10 \mathrm{ppmv}$ in $\mathrm{N}_{2}$ ) with an aqueous slurry saturated with $\mathrm{NaNO}_{2}$ (Sigma-Aldrich) (Reaction R9):

$\mathrm{Cl}_{2}(g)+\mathrm{NO}_{2}^{-}(\mathrm{aq}) \rightleftharpoons \mathrm{ClNO}_{2}(g)+\mathrm{Cl}^{-}(\mathrm{aq})$.

This gas stream was periodically added to the main inlet with the aid of a normally open two-way valve connected to a vacuum pump in a similar fashion as described earlier for $\mathrm{N}_{2} \mathrm{O}_{5}$ and PAN (Tokarek et al., 2014; Odame-Ankrah and Osthoff, 2011). The $\mathrm{ClNO}_{2}$ content of the calibration gas stream was quantified by thermal dissociation cavity ring-down spectroscopy (TD-CRDS) as described in Sect. 2.2.2. In total, 31 calibrations for $\mathrm{ClNO}_{2}$ were carried out, spread out evenly over the measurement period. The iCIMS response factor at $m / z 208$ was $(0.40 \pm 0.06) \mathrm{Hzpptv}^{-1}$ (where the error represents the standard deviation of repeated calibrations), normalized to $10^{6}$ counts of reagent ion at $m / z 127$. The ${ }^{37} \mathrm{ClNO}_{2} \mathrm{I}^{-}$ion at $m / z, 210$ was also monitored and found to be $(0.298 \pm 0.004)$ times the signal at $m / z 208\left(r^{2}=0.944\right)$, slightly lower than Standard Mean Ocean Chloride ${ }^{37} \mathrm{Cl}$ mole fraction in seawater of $\sim 0.319$ (Wieser and Berglund, 2009) and our previously observed ratios of $0.315 \pm 0.003$ in Calgary (Mielke et al., 2011) and $0.3065 \pm 0.0002$ in Pasadena (Mielke et al., 2013). The reason(s) for these differences is unclear but they may be a result of fractionation processes (Koehler and Wassenaar, 2010; Volpe et al., 1998), a topic outside the scope of this paper.

The iCIMS was also used to quantify mixing ratios of PAN at $m / z 59$ and PPN at $m / z 73$ (Slusher et al., 2004; Mielke et al., 2011; Mielke and Osthoff, 2012). For this reason, part of the instrument's inlet prior to the ion-molecule reaction region was heated to $190^{\circ} \mathrm{C}$ to dissociate PANs into their respective peroxyacyl radicals and $\mathrm{NO}_{2}$. Further, the collisional dissociation chamber (CDC) was operated in declustering mode $(-22.7 \mathrm{~V})$ to break up ion clusters. Calibrations and matrix effect correction procedures and a time series of the PAN and PPN data were presented by Tokarek et al. (2014).

\subsubsection{Quantification of $\mathrm{NO}_{2}$ and $\mathrm{N}_{2} \mathrm{O}_{5}$ by cavity ring-down spectroscopy}

The CRDS used in this work was an amalgamated version of two instruments described earlier (Paul and Osthoff, 2010; Odame-Ankrah and Osthoff, 2011), called Improved Detection Instrument for Nitrogen Oxide Species (iDinos) (Odame-Ankrah, 2015). A schematic of the optical layout is shown in Fig. 2. The optical bread board, instrument frame, electronic, and data acquisition components were as described by Paul and Osthoff (2010). The new instrument was set up with up to six parallel detection channels: four $405 \mathrm{~nm}$ "blue" diode laser CRDS cells for quantification at $\mathrm{NO}_{2}$ via its absorption at $405 \mathrm{~nm}$ with a distance between the pairs of high-reflectivity (HR) mirrors (Advanced Thin Films) of $112.5 \mathrm{~cm}$, of which $92.0 \mathrm{~cm}$ were filled with sample air, and two newly constructed $662 \mathrm{~nm}$ "red" diode laser CRDS cells for quantification at $\mathrm{NO}_{3}$ via its absorption at $662 \mathrm{~nm}$ with a distance between the HR mirrors (Los Gatos) of $93.0 \mathrm{~cm}$ of which $73.0 \mathrm{~cm}$ were filled with sample air. Light exiting the far ends of the CRDS cells was collected using fixedfocus collimating lenses and multi-mode optical fibers (Thorlabs) connected to photomultiplier tubes (PMTs; Hamamatsu H9433-03MOD) with $10 \mathrm{MHz}$ bandwidth. Bandpass filters (Thorlabs FB405-10 and FB660-10) were placed between the PMTs and the end of the optical fibers. 
Table 1. Summary of measurement techniques deployed at T45 during the study.

\begin{tabular}{|c|c|c|c|}
\hline $\begin{array}{l}\text { Species or } \\
\text { parameter }\end{array}$ & Method & $\begin{array}{l}\text { Uncer- } \\
\text { tainty }\end{array}$ & $\begin{array}{r}\text { Time } \\
\text { resolution }\end{array}$ \\
\hline $\mathrm{ClNO}_{2}, \mathrm{PAN}, \mathrm{PPN}$ & Chemical ionization mass spectrometry (Mielke et al., 2011) & $\pm 25 \% \pm 10 \%$ & $30 \mathrm{~s}$ \\
\hline $\mathrm{N}_{2} \mathrm{O}_{5}$ & $\begin{array}{l}\text { Red diode laser cavity ring-down spectroscopy } \\
\text { (Odame-Ankrah and Osthoff, 2011) }\end{array}$ & $\pm 25 \%$ & $1 \mathrm{~s}$ \\
\hline $\mathrm{O}_{3}$ & UV absorption (Thermo 49i) & $\pm 10 \%$ & $10 \mathrm{~s}$ \\
\hline $\mathrm{NO} / \mathrm{NO}_{y}$ & $\begin{array}{l}\mathrm{O}_{3} \text {-Chemiluminescence (Thermo } 42 \mathrm{i}-\mathrm{Y} \text { ) with heated Mo } \\
\text { converter; operated with inlet filter }\end{array}$ & $\pm 30 \%$ & $10 \mathrm{~s}$ \\
\hline $\mathrm{NO}_{2}$ & $\begin{array}{l}\text { Blue diode laser cavity ring-down spectroscopy } \\
\text { (Paul and Osthoff, 2010) }\end{array}$ & $\pm 10 \%$ & $1 \mathrm{~s}$ \\
\hline PAN, PPN & $\begin{array}{l}\text { Gas chromatography with electron capture detection } \\
\text { (Tokarek et al., 2014) }\end{array}$ & $\pm 10 \%$ & $6 \min$ \\
\hline Photolysis frequencies & Spectral radiometry (Metcon) & $\pm 20 \%$ & $10 \mathrm{~s}$ \\
\hline Aerosol size distribution & Scanning mobility particle sizer (SMPS) & not available & $15 \mathrm{~min}$ \\
\hline Aerosol composition & Aerosol Chemical Speciation Monitor (ACSM) & $\pm 20 \%$ & $30 \mathrm{~min}$ \\
\hline VOCs & Agilent & $\pm 30 \%$ & $20 \min \left(1 h^{a}\right)$ \\
\hline Meteorological data & Various & & \\
\hline
\end{tabular}

The two laser diodes were simultaneously square-wave modulated by a function generator (SRS DS335). The PMT voltages were digitized using an eight-channel 14-bit data acquisition card (National Instruments PCI-6133; $2.5 \mathrm{MS} \mathrm{s}^{-1}$ simultaneous sampling sample rate) connected to a laptop computer via a PCMCIA-to-PCI expansion unit (Magma CB4DRQ) and controlled by software written in LabVIEW ${ }^{\mathrm{TM}}$ (National Instruments).

Ring-down time constants $(\tau)$ were determined from a linear fit to the logarithm of the digitized PMT voltage as described by Brown et al. (2002) immediately after acquisition of the ring-down traces (which were co-added to a user-selectable averaging time prior to the fit). The fitting algorithm requires the subtraction of the PMT voltage offset prior to taking the logarithm; this offset was measured between ring-down events after the signal had returned to baseline, which limited the repetition rate of the diode lasers and the number of traces averaged per second to a frequency of $300 \mathrm{~Hz}$.

Ring-down time constants in the absence of the target absorber $\left(\tau_{0}\right)$ were determined by flooding the inlet (each once per hour) with ultra-pure, or "zero", air (Praxair) for the $405 \mathrm{~nm}$ channels and by titration with NO for the $662 \mathrm{~nm}$ channel (Brown et al., 2001; Simpson, 2003). Typical values of $\tau_{0}$ were in the range of 63 to $67 \mu$ s and between 198 and $210 \mu$ s for the blue and red channels, respectively. The baseline precision (i.e., standard deviation, $\sigma$ ) of the $\mathrm{NO}_{2}$ and $\mathrm{NO}_{3}$ measurements were \pm 80 and \pm 3 pptv ( $1 \mathrm{~s}$ data), respectively. For the $\mathrm{NO}_{3}$ channels, additional noise was introduced by variable background absorption of $\mathrm{NO}_{2}, \mathrm{O}_{3}$, and water vapour which produce small, spurious structure in the $662 \mathrm{~nm}$ absorption signal (Dubé et al., 2006) and were not tracked well by the interpolation of the baseline from the hourly $\tau_{0}$ determinations.

During the Abbotsford campaign, only five (four blue and one red) CRDS channels were operated because of delays in the fabrication of the final set of CRDS mirror holders. The 662 nm CRDS cell sampled from a Teflon ${ }^{\mathrm{TM}}$ inlet heated to $130^{\circ} \mathrm{C}$ for quantification of $\mathrm{NO}_{3}$ plus the $\mathrm{NO}_{3}$ generated from thermal dissociation $\mathrm{N}_{2} \mathrm{O}_{5}$ (Brown et al., 2001; Simpson, 2003; Dubé et al., 2006). Under the high-NO $\mathrm{NO}_{x}$ conditions of this study, equilibrium (2) was sufficiently far to the right (see Sect. 3.3) such that $\left[\mathrm{NO}_{3}\right]+\left[\mathrm{N}_{2} \mathrm{O}_{5}\right] \approx\left[\mathrm{N}_{2} \mathrm{O}_{5}\right]$; i.e., the concentration measured could be equated with $\left[\mathrm{N}_{2} \mathrm{O}_{5}\right]$ without introducing a large error (i.e., <5\%). The four $405 \mathrm{~nm}$ CRDS cells were operated as follows: the first sampled from an ambient temperature inlet and was used to quantify $\mathrm{NO}_{2}$. The second sampled from a quartz inlet heated to $250{ }^{\circ} \mathrm{C}$ and was used to quantify $\mathrm{NO}_{2}$ plus total peroxyacyl nitrate ( $\Sigma$ PAN) (Paul et al., 2009; Paul and Osthoff, 2010). Data from this channel will be presented in a future publication. The third was operated with a quartz inlet heated to $450{ }^{\circ} \mathrm{C}$ to enable $\mathrm{ClNO}_{2}$ calibrations (Thaler et al., 2011). Quantification of total alkyl nitrates $(\Sigma \mathrm{AN})$ in ambient air was not attempted because of the high $\mathrm{NO}_{x}$ levels and resulting large subtraction errors (Thieser et al., 2016). The 


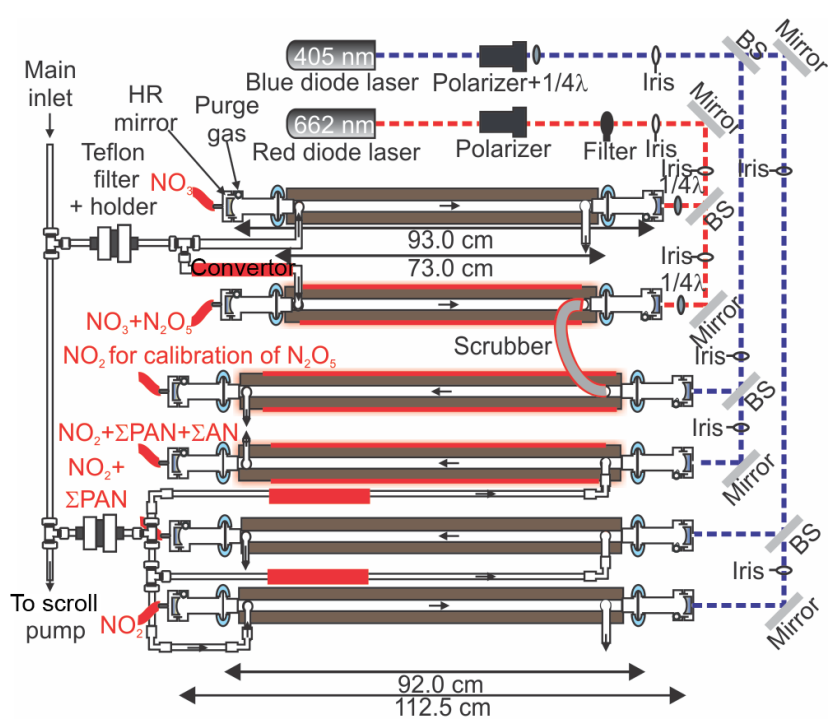

Figure 2. Optical layout of the cavity ring-down spectrometer. 1/4 $\lambda$ refers to quarter-wave plate. BS is the beam splitter. HR mirror refers to the high-reflectivity mirror. Drawing is not to scale.

fourth $405 \mathrm{~nm}$ CRDS cell was connected with polycarbonate tubing ( $3 / 8 \mathrm{in}$. OD and $1 / 4 \mathrm{in}$. ID) in series to the $662 \mathrm{~nm}$ channel and was used to calibrate the response of the $\mathrm{N}_{2} \mathrm{O}_{5}$ channel, which is a function of the transmission efficiency of $\mathrm{N}_{2} \mathrm{O}_{5}$ through the inlet and the overlap of the diode laser spectrum with the $\mathrm{NO}_{3}$ absorption line (Odame-Ankrah and Osthoff, 2011). The role of the polycarbonate tube was to scrub $\mathrm{NO}_{3}$ exiting the $\mathrm{N}_{2} \mathrm{O}_{5}$ channel, allowing detection of only the $\mathrm{NO}_{2}$ generated from thermal dissociation of $\mathrm{N}_{2} \mathrm{O}_{5}$ and to prevent recombination of $\mathrm{NO}_{3}$ and $\mathrm{NO}_{2}$ in the blue calibration channel (Wagner et al., 2011).

$\mathrm{N}_{2} \mathrm{O}_{5}$ was generated in situ by adding an excess of $\mathrm{O}_{3}$ (generated by passing $\mathrm{O}_{2}$ past a $254 \mathrm{~nm} \mathrm{Hg}$ lamp) to nitric oxide (NO) in a $0.635 \mathrm{~cm}(1 / 4 \mathrm{in}$.) OD and $0.476 \mathrm{~cm}$ (3/16 in.) ID Teflon ${ }^{\mathrm{TM}}$ calibration line and allowed to equilibrate (i.e., until the output was constant) offline before being switched inline on demand. The $\mathrm{N}_{2} \mathrm{O}_{5}$ response (which accounted for $\mathrm{N}_{2} \mathrm{O}_{5}$ loss in the sampling line and slight mismatches of the laser wavelengths with the $\mathrm{NO}_{3}$ absorption line) varied between 65 and $100 \%$ and depended on inlet "age"; the Teflon ${ }^{\mathrm{TM}}$ inlet and aerosol inlet filter were changed every 2-3 days. The accuracy of the $\mathrm{NO}_{2}$ and $\mathrm{N}_{2} \mathrm{O}_{5}$ data were \pm 10 and $\pm 25 \%$, respectively, driven mainly by the systematic uncertainty of the $\mathrm{NO}_{2}$ absorption cross section and of the $\mathrm{N}_{2} \mathrm{O}_{5}$ inlet transmission efficiency (Odame-Ankrah, 2015).

\subsubsection{Measurements of $\mathrm{O}_{3}, \mathrm{NO}$, and $\mathrm{NO}_{y}$}

Mixing ratios of $\mathrm{O}_{3}$ were monitored by UV absorption in a commercial instrument (Thermo 49) and were accurate within $\pm 2 \%$ and \pm 1 ppbv. An $\mathrm{NO}-\mathrm{O}_{3}$ chemiluminescence instrument (Thermo 42i) was used to monitor mixing ratios of $\mathrm{NO}$ and $\mathrm{NO}_{y}$, which was reduced to $\mathrm{NO}$ in a Mo converter heated to $\sim 320^{\circ} \mathrm{C}$ placed outside a short distance $(\sim 1 \mathrm{~m})$ from the sample inlet. This instrument sampled from the main inlet via a Teflon ${ }^{\mathrm{TM}}$ filter and filter holder and was calibrated daily against CRDS as described by Tokarek et al. (2014). The slope uncertainty for each multipoint calibration was $\pm 15 \%$. Interpolation between calibration runs gave an overall uncertainty of $\pm 30 \%$. The NO zero offset uncertainty (needed for calculating the $\mathrm{NO}_{3}$ loss rate with respect to reaction with $\mathrm{NO}$, Reaction $\mathrm{R} 9$ ) was \pm 10 pptv.

\subsubsection{VOC measurements}

Volatile organic compounds were monitored with a commercial gas chromatograph-mass spectrometer (GC-MS; Agilent model 7890A and 5975C) equipped with an FID detector and a Markes Unity 2 pre-concentrator with an ozone precursor trap cooled to $-25^{\circ} \mathrm{C}$.

In a typical sampling sequence, a $500 \mathrm{~mL}$ air sample was collected at a flow rate of $25 \mathrm{~mL} \mathrm{~min}^{-1}$, taken from the centre flow of a $1.27 \mathrm{~cm}(1 / 2 \mathrm{in}$.) stainless steel inlet line which was continuously sampling ambient air at $5 \mathrm{~L} \mathrm{~min}^{-1}$. The sampled air flowed through a $0.318 \mathrm{~cm}(1 / 8 \mathrm{in}$.) stainless steel line and particles were removed using a $1 \mu \mathrm{m}$ pore size fritted filter. Once $500 \mathrm{~mL}$ of air were collected, the preconcentrator was flushed with helium to remove air while awaiting injection. At the start of a GC run, the sample in the pre-concentrator was flash heated to $300^{\circ} \mathrm{C}$ and held for $3 \mathrm{~min}$. The sample was separated on two columns with the entire sample going through the Agilent VRX column with a Dean switch directing the first gases emitted to a second GasPro column and then to the FID detector $(\sim<\mathrm{C} 4)$, while the heavier compounds were detected using the MS detector in scan mode.

The cycle time for the GC analysis was $1 \mathrm{~h}$ with the sample being collected during the previous runs analyses. The 20 min sample was taken at the start of a $1 \mathrm{~h}$ time period.

Due to the low temperature of the trap, the air was dried using a trap at $-30^{\circ} \mathrm{C}$. The trap was heated and dried between each sample and reconditioned for $10 \mathrm{~min}$ prior to sample collection. All sample lines were stainless steel with a Restek Sulfinert ${ }^{\mathrm{TM}}$ coating to minimize sample loss on the lines. Calibrations were performed once per day for 105 species using a 100 ppbv US Environmental Protection Agency (EPA) photochemical assessment monitoring system (PAMS) and a 100 ppb EPA air method, toxic organics - 15 (TO15) standard at an approximate concentration. The terpenes were semi-quantitatively measured as a calibration source was not available at the time and only the changes in concentration 
Table 2. Ratios of up- to down-welling photolysis frequencies.

\begin{tabular}{lr}
\hline Frequency & Ratio \\
\hline$j\left(\mathrm{NO}_{3}\right)$ & $0.27 \pm 0.04$ \\
$j\left(\mathrm{NO}_{2}\right)$ & $0.15 \pm 0.03$ \\
$j\left(\mathrm{ClNO}_{2}\right)$ & $0.14 \pm 0.02$ \\
$j\left(\mathrm{O}_{3} \rightarrow \mathrm{O}\left({ }^{1} \mathrm{D}\right)\right)$ & $0.11 \pm 0.02$ \\
\hline
\end{tabular}

strength with time of day were used. The accuracy of the measurements varied depending on the species but was better than $\pm 30 \%$ throughout. Peaks were manually reintegrated using Chemstation software from Agilent. Table S1 in the Supplement summarizes the VOCs quantified.

\subsection{Aerosol measurements}

The chemical composition of non-refractory $\mathrm{PM}_{1}$ was monitored using an Aerosol Chemical Speciation Monitor (ACSM, Aerodyne), which reported concentrations of $\mathrm{NO}_{3}^{-}$, $\mathrm{SO}_{4}^{2-}, \mathrm{Cl}^{-}, \mathrm{NH}_{4}^{+}$, and total organics. A general description of this instrument designed for routine monitoring has been given by $\mathrm{Ng}$ et al. (2011). The composition of the refractory aerosol (i.e., sea salt) was not quantified.

Submicron aerosol size distributions were quantified by a scanning mobility particle sizer (SMPS, TSI 3034). This instrument measured aerosol particles in the range from 10 to $487 \mathrm{~nm}$ using 54 size channels (32 channels per decade). Both of these instruments were housed in a trailer operated by Metro Vancouver. The ACSM and the SMPS sampled air off a shared stainless steel inlet that had a total flow of $5 \mathrm{~L} \mathrm{~min}^{-1}$ and contained a $\mathrm{PM}_{2.5}$ sharp cut filter at the inlet and was operated at ambient relative humidity.

\subsection{Photolysis frequencies}

Photolysis frequencies were determined by solar actinic flux spectroradiometry (Hofzumahaus et al., 1999) using a commercial radiometer with $2 \pi$ receptor optics and photodiode array (PDA) detector (Metcon; 512 pixels, wavelength range $285-690 \mathrm{~nm}$ ) calibrated by the manufacturer. The spectrometer was mounted facing up (zenith view) and hence measured the down-welling radiation. On several days, the spectrometer was inverted hourly to determine the up-welling radiation, which was added to the down-welling flux. Photolysis frequencies including $j\left(\mathrm{NO}_{3}\right), j\left(\mathrm{NO}_{2}\right), j\left(\mathrm{O}^{1} \mathrm{D}\right)$, and $j\left(\mathrm{ClNO}_{2}\right)$ were calculated using reference spectra and quantum yields from Sander et al. (2010) and Ghosh et al. (2012). Table 2 gives the ratio of observed up-welling to down-welling for selected photolysis frequencies. For 3 August (a cloud-free day), the measurements were compared to (hourly) predictions with the online Tropospheric Ultraviolet and Visible (TUV) radiation model V5.0 (Madronich and Flocke, 1997); with default settings, the model reproduced the measured $j\left(\mathrm{NO}_{2}\right)$ and $j\left(\mathrm{O}^{1} \mathrm{D}\right)$ quite well: a scatter plot of observed against TUV rate constants had correlation coefficients $(r)$ of 0.997 and 0.998 , slopes of $1.06 \pm 0.02$ and $1.10 \pm 0.02$, and offsets of $(3 \pm 1) \times 10^{-4} \mathrm{~s}^{-1}$ and $(5 \pm 3) \times 10^{-7} \mathrm{~s}^{-1}$.

\subsection{Box model simulations of the nocturnal $\mathrm{O}_{3}$ and $\mathrm{O}_{x}$ loss in the NBL}

A box model was set up to reconcile the median nocturnal decays of $\mathrm{O}_{3}$ and $\mathrm{O}_{x}$. These simulations are intended as back-of-the-envelope type estimates of major processes only since an accurate description of the nocturnal boundary layer chemistry would require modelling of horizontal and vertical transport, i.e., altitude-resolved information not available in this study (Geyer and Stutz, 2004). The model's assumptions are a well-mixed NBL that is decoupled from the NRL above it as observed by earlier balloon vertical profiling (Pisano et al., 1997), $\mathrm{O}_{3}$ and $\mathrm{NO}_{2}$ dry deposition velocities of $v_{\mathrm{d}}\left(\mathrm{O}_{3}\right)=0.2 \mathrm{~cm} \mathrm{~s}^{-1}$ and $v_{\mathrm{d}}\left(\mathrm{NO}_{2}\right)=\alpha \times v_{\mathrm{d}}\left(\mathrm{O}_{3}\right)$ with $\alpha=0.65$ (Lin et al., 2010), and negligible chemical $\mathrm{O}_{3}$ and $\mathrm{O}_{x}$ losses other than titration of $\mathrm{O}_{3}$ by NO (Reaction R8) and by reaction with a generic biogenic hydrocarbon (assumed to react with $\mathrm{O}_{3}$ with a rate coefficient of $5 \times 10^{-11} \mathrm{~cm}^{3} \mathrm{molec}^{-1} \mathrm{~s}^{-1}$, i.e., the rate coefficient for reaction of $\alpha$-pinene with $\mathrm{O}_{3}$; Seinfeld and Pandis, 2006). Simulations were initiated with the median $\mathrm{NO}_{2}$ and $\mathrm{O}_{3}$ concentrations observed at sunset. More details are given in the Supplement.

\section{Results}

\subsection{Overview of data set}

\subsubsection{Meteorology}

A time series of local wind direction and speed are displayed in Fig. 3d. During the 2-week-long measurement period, the air flow to the site was from the Pacific Ocean to the SW and WSW with a moderate wind speed of $8.7 \mathrm{~km} \mathrm{~h}^{-1}$ (median value). On most nights, local wind speeds were calm, i.e., $<5 \mathrm{~km} \mathrm{~h}^{-1}$ (median speed $3.6 \mathrm{~km} \mathrm{~h}^{-1}$ ) and from variable directions, though predominantly from the $\mathrm{W}$ and $\mathrm{N}$. The two exceptions were the nights of 22-23 July and 1-2 August when stronger winds $\left(>5 \mathrm{~km} \mathrm{~h}^{-1}\right)$ from the $\mathrm{W}$ and SW persisted. These nights saw relatively high $\mathrm{ClNO}_{2}$ mixing ratios (see Sect. 3.1.4)

The air temperatures were quite mild and ranged from a minimum of $11.0^{\circ} \mathrm{C}$ to a maximum of $31.9^{\circ} \mathrm{C}$. The warm temperatures shifted equilibrium $\mathrm{K}_{2}$ from $\mathrm{N}_{2} \mathrm{O}_{5}$ towards $\mathrm{NO}_{3}$ and $\mathrm{NO}_{2}$ (further analyzed in Sect. 3.2.2). At night, temperatures frequently dropped to the dew point, resulting in occasional fog formation (shown as grey rectangles in Figure 3D), sometimes after sunrise. Fog droplets are strong sinks for $\mathrm{N}_{2} \mathrm{O}_{5}$ (Osthoff et al., 2006). In total, the impact of fog was minor, affecting $5 \%$ of the data. In addition, there were two periods with precipitation: the first occurred inter- 
mittently on 20 July until the morning of 21 July. The second rainfall event was a $24 \mathrm{~h}$ period from mid-day 22 July to the afternoon of 23 July (shown as blue dots in Fig. 3d). 23 July also exhibited the highest wind speeds of the campaign (Fig. 3c) and lowest daytime photolysis frequencies. The time series of $j\left(\mathrm{ClNO}_{2}\right)$ is shown as a representative example in Fig. 3a. The photolysis data indicate that it was sunny on 6 days $(25,26,29$ July and 1, 4, 5 August) and that the remaining days had variable cloud cover, consistent with hourly meteorological logs that showed $10 \%$ of the measurement period affected by precipitation.

\subsection{2 $\mathrm{NO}$ and $\mathrm{NO}_{2}$}

The rates of $\mathrm{N}_{2} \mathrm{O}_{5}$ and $\mathrm{ClNO}_{2}$ formation depend on the rate of $\mathrm{NO}_{3}$ production, $P\left(\mathrm{NO}_{3}\right)=k_{1}\left[\mathrm{NO}_{2}\right]\left[\mathrm{O}_{3}\right]$ (analyzed further in Sect. 3.2.2); therefore, it is informative to first examine the mixing ratios of $\mathrm{NO}_{2}$ and $\mathrm{O}_{3}$ (see Sect. 3.1.3). The time series of $\mathrm{NO}, \mathrm{NO}_{2}, \mathrm{O}_{3}$, and $\mathrm{O}_{x}\left(\mathrm{O}_{3}+\mathrm{NO}_{2}\right)$ mixing ratios are shown in Fig. 3c, and their diurnal averages are shown as 10th, 25th, 50th, 75th, and 90th percentiles in Fig. $4 \mathrm{~b}$ and c.

The median $\mathrm{NO}$ and $\mathrm{NO}_{2}$ mixing ratios for the entire campaign were 0.9 and 5.9 ppbv, respectively. The average $\mathrm{NO}_{\mathrm{x}} / \mathrm{NO}_{\mathrm{y}}$ ratio for the entire campaign was $0.9 \pm 0.4$. These concentration levels are characteristic of an urban air mass impacted by relatively fresh emissions from combustion engines in automobiles.

At night, mixing ratios of $\mathrm{NO}$ were generally lower than during the day though not negligible (median $0.3 \mathrm{ppbv}$, Fig. 4b) as $\mathrm{NO}$ was oxidized by $\mathrm{O}_{3}$ to $\mathrm{NO}_{2}$ (Reaction R8) and was not replenished by $\mathrm{NO}_{2}$ photolysis. However, mixing ratios of NO increased throughout the night, often coinciding with complete nocturnal removal of $\mathrm{O}_{3}$ (see Sect. 3.1.3), which indicates the presence of nearby combustion sources of $\mathrm{NO}_{x}$ (most likely automobile exhaust). The presence of $\mathrm{NO}$ titrates $\mathrm{NO}_{3}$ (Reaction R3) and effectively shut down $\mathrm{N}_{2} \mathrm{O}_{5}$ and $\mathrm{ClNO}_{2}$ production for most of the study: $68 \%$ of the measurement period had NO mixing ratios $>100 \mathrm{pptv}$ and $\mathrm{NO}_{3}$ lifetimes (with respect to its reaction with $\mathrm{NO}$ ) of $<15$ s. In contrast, $\mathrm{NO}_{2}$ mixing ratios were highest at night (median 7.3 ppbv), amplified further by $\mathrm{NO}_{x}$ emissions that continued throughout the night and likely by low nocturnal mixing heights (see discussion).

Mixing ratios of $\mathrm{NO}$ and $\mathrm{NO}_{x}$ were highest in the morning hours. Concentration changes at this time of day are difficult to interpret since the NBL breaks up during this time, resulting in vertical mixing of air masses, photolabile species (e.g., $\mathrm{ClNO}_{2}, \mathrm{HONO}, \mathrm{N}_{2} \mathrm{O}_{5}$ ) that accumulated overnight begin to photodissociate, and local emissions change with the onset of rush hour.

In contrast to the morning increase in NO, an afternoon/early evening maximum in NO was absent. This can be rationalized by a greater mixing height and abundance of oxidants that oxidize $\mathrm{NO}$ to $\mathrm{NO}_{2}$, i.e., $\mathrm{O}_{3}$ (see Figs. 3 and 4 and Sect. 3.1.3) and organic peroxy radicals in the afternoon, a topic outside the scope of this paper.

\subsection{3 $\mathrm{O}_{3}$ and $\mathrm{O}_{x}$}

The time series of $\mathrm{O}_{3}$ mixing ratios and its diurnal profile are shown in Figs. $3 \mathrm{c}$ and $4 \mathrm{c}$, respectively. $\mathrm{O}_{3}$ mixing ratios were small (average \pm 1 standard deviation of $16 \pm 12 \mathrm{ppbv}$ ) and peaked at $\sim 17: 00$ PDST in the afternoon. The highest concentrations were observed on August 4 from 13:55 to 15:30, when mixing ratios were $64 \pm 1 \mathrm{ppbv}$ (the $8 \mathrm{~h}$ running average was $52 \mathrm{ppbv}$ ). These levels were well below the CAAQS $8 \mathrm{~h}$ standard of $63 \mathrm{ppbv}$ and the $1 \mathrm{~h}$ National Ambient Air Quality Objective of $82 \mathrm{ppbv}$, smaller than the pre-2003 data analyzed by Ainslie and Steyn (2007), who reported between 10 and $20 \mathrm{O}_{3} 1 \mathrm{~h}$ exceedances of $82 \mathrm{ppbv}$ in the 1980s, and of similar magnitude as observed by a high-density monitoring network in the region in 2012 (Bart et al., 2014), which observed peak $\mathrm{O}_{3}$ levels of 74 and 83 ppbv at Abbotsford on 8 July and 17 August, respectively.

A recurring feature of this data set was the rapid and often complete loss of $\mathrm{O}_{3}$ at night (Fig. 4c). This was accompanied by an increase in the $\mathrm{NO}_{2}$ mixing ratios, though by less $\left(+6 \mathrm{ppbv}\right.$ on average) than the amount of $\mathrm{O}_{3}$ that was lost ( -26 ppbv on average), showing that $\mathrm{NO}$ to $\mathrm{NO}_{2}$ conversion (Reaction R8) was a contributor, though minor $(\sim 25 \%)$ to the nocturnal $\mathrm{O}_{3}$ loss.

The diurnal profile of $\mathrm{O}_{x}$ was similar to that of $\mathrm{O}_{3}$, in that the highest concentrations occurred in the afternoon (at $\sim$ 18:00) and a considerable fraction of $\mathrm{O}_{x}$ was removed at night. At sunset, a median amount of $26 \mathrm{ppbv}$ of $\mathrm{O}_{x}$ were present, which decreased to $12 \mathrm{ppbv}$ at sunrise (Fig. 4c). The pathways contributing to nocturnal $\mathrm{O}_{3}$ and $\mathrm{O}_{x}$ loss are probed using box model simulations in Sect. 3.2.1.

There were two (out of 16 total) nights when $\mathrm{O}_{3}$ was not completely removed. On 22-23 July and 1-2 August, $\mathrm{O}_{3}$ mixing ratios dropped from a daytime maxima of $\sim 33 \mathrm{ppbv}$ to non-zero nocturnal minima of $\sim 16 \mathrm{ppbv}$. On both of these nights, $\mathrm{ClNO}_{2}$ and $\mathrm{N}_{2} \mathrm{O}_{5}$ mixing ratios were elevated (Fig. 3a), and the two largest $\mathrm{ClNO}_{2}$ to $\mathrm{NO}_{y}$ ratios were observed (Fig. 3b). The local wind speeds were $>6 \mathrm{~km} \mathrm{~h}^{-1}$, whereas on other nights, local winds were calmer (Fig. 3c). The greater local wind speeds likely induced more turbulence and a higher vertical mixing height.

\subsection{4 $\mathrm{N}_{2} \mathrm{O}_{5}$ and $\mathrm{ClNO}_{2}$}

Time series of $\mathrm{ClNO}_{2}$ and $\mathrm{N}_{2} \mathrm{O}_{5}$ mixing ratios and $\mathrm{ClNO}_{2}$ photolysis frequencies are shown in Fig. 3a. Mixing ratios of $\mathrm{ClNO}_{2}$ and $\mathrm{N}_{2} \mathrm{O}_{5}$ were small (campaign averages at night of 4.0 and $1.4 \mathrm{pptv}$, respectively). The mixing ratios peaked prior to sunrise at median values of 7.9 and $7.8 \mathrm{pptv}$ for $\mathrm{ClNO}_{2}$ and $\mathrm{N}_{2} \mathrm{O}_{5}$, respectively. The highest mixing ratios of this campaign were 97 pptv for $\mathrm{ClNO}_{2}$ and 23 pptv for $\mathrm{N}_{2} \mathrm{O}_{5}$, both observed on the night of 1-2 August. This night was 


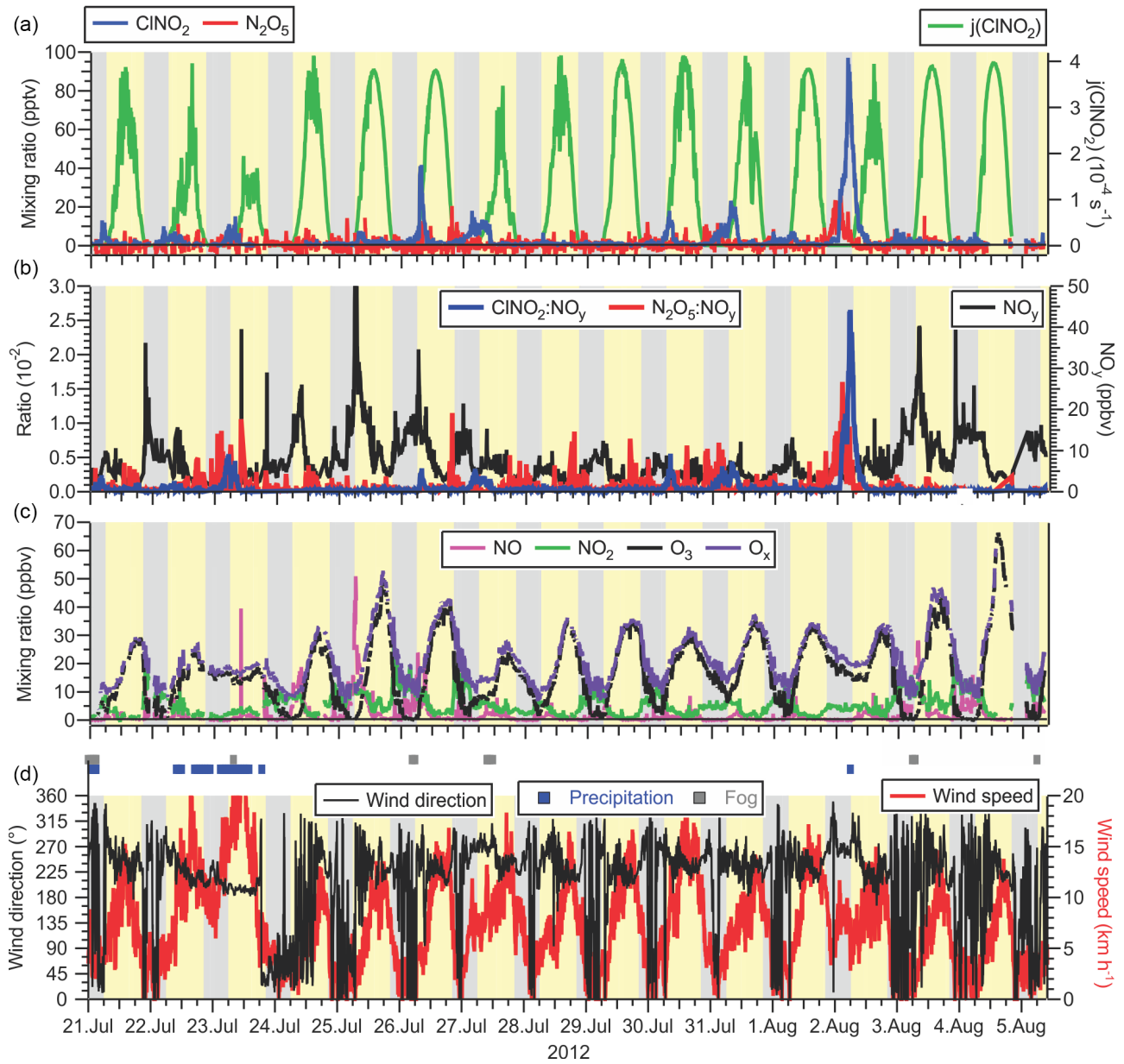

Figure 3. (a) Time series of $\mathrm{N}_{2} \mathrm{O}_{5}$ and $\mathrm{ClNO}_{2}$ mixing ratios (left axis) and $\mathrm{ClNO}_{2}$ photolysis frequency (right axis) observed at $\mathrm{T} 45$ near the Abbotsford International Airport. (b) Time series of the ratios of $\mathrm{ClNO}_{2}$ and $\mathrm{N}_{2} \mathrm{O}_{5}$ to $\mathrm{NO}_{y}$ (left axis) and of $\mathrm{NO}_{y}$ (right axis). (c) Time series of $\mathrm{NO}, \mathrm{NO}_{2}, \mathrm{O}_{3}$, and $\mathrm{O}_{x}\left(=\mathrm{NO}_{2}+\mathrm{O}_{3}\right)$ mixing ratios. (d) Time series of local wind direction (left axis) and speed (right axis). The blue and grey dots above the time series indicates periods of precipitation (drizzle or rain) and fog, respectively, as identified in hourly meteorological logs.

also the only time when nocturnal $\mathrm{ClNO}_{2}$ mixing ratios exceeded 20 pptv and is analyzed in greater detail in Sect. 3.2.3.

Consistent with their low mixing ratios, neither $\mathrm{ClNO}_{2}$ nor $\mathrm{N}_{2} \mathrm{O}_{5}$ were significant components of $\mathrm{NO}_{y}$ (Fig. 3b): on average, they contributed $0.1 \%$ to the nocturnal $\mathrm{NO}_{y}$ budget, though $\mathrm{NO}_{y}$ mixing ratios were large (median $6.3 \mathrm{ppbv}$ at night), typical for a site impacted by urban emissions. The only exception was the night of $1-2$ August, when $\mathrm{ClNO}_{2}$ and $\mathrm{N}_{2} \mathrm{O}_{5}$ constituted 2.6 and $1.6 \%$ of $\mathrm{NO}_{y}$, respectively, and $\mathrm{NO}_{y}$ mixing ratios were $4.4 \mathrm{ppbv}$ on average (Fig. $3 \mathrm{~b}$ ).

The $\mathrm{ClNO}_{2}$ and $\mathrm{N}_{2} \mathrm{O}_{5}$ mixing ratios are displayed as functions of time of day in Fig. 4a. Before midnight local time, $\mathrm{N}_{2} \mathrm{O}_{5}$ mixing ratios were slightly larger (median value of 1.8 pptv on average) than those of $\mathrm{ClNO}_{2}$ (median value of 1.4 pptv on average), whereas after midnight $\mathrm{ClNO}_{2}$ mixing ratios were larger than those of $\mathrm{N}_{2} \mathrm{O}_{5}(2.0 \mathrm{vs} .0 .6 \mathrm{pptv})$. The latter is consistent with observations at other ground sites, which generally showed higher concentrations of the longer- lived $\mathrm{ClNO}_{2}$ prior to sunset (Thornton et al., 2010; Mielke et al., 2013). The higher $\mathrm{N}_{2} \mathrm{O}_{5}$ than $\mathrm{ClNO}_{2}$ abundances at the beginning of the nights suggest that the $\mathrm{N}_{2} \mathrm{O}_{5}$ production rate at that time exceeded its ability to react heterogeneously and convert to $\mathrm{ClNO}_{2}$, potentially due to a lack of available aerosol chloride or otherwise reduced $\mathrm{N}_{2} \mathrm{O}_{5}$ heterogeneous uptake parameters (Thornton et al., 2010).

Production of $\mathrm{ClNO}_{2}$ from $\mathrm{N}_{2} \mathrm{O}_{5}$ uptake on aerosol ceases after sunrise because of the rapid removal of $\mathrm{N}_{2} \mathrm{O}_{5}$ and $\mathrm{NO}_{3}$ as the latter is titrated by $\mathrm{NO}$ and destroyed by photolysis (Reactions R3, R4) (Wayne et al., 1991). In spite of this, $\mathrm{ClNO}_{2}$ mixing ratios frequently (on 12 out of 15 measurement days) continued to increase after sunrise (Figs. 3a and 4 ), peaking on average at $\sim 07: 45$ in the morning approximately $2 \mathrm{~h}$ after sunrise. The median mixing ratio at that time was $6.7 \mathrm{pptv}$ larger than the median value of $5.3 \mathrm{pptv}$ observed at sunrise. The most prominent example of this phenomenon occurred on the morning of 26 July. For a 2-hour 


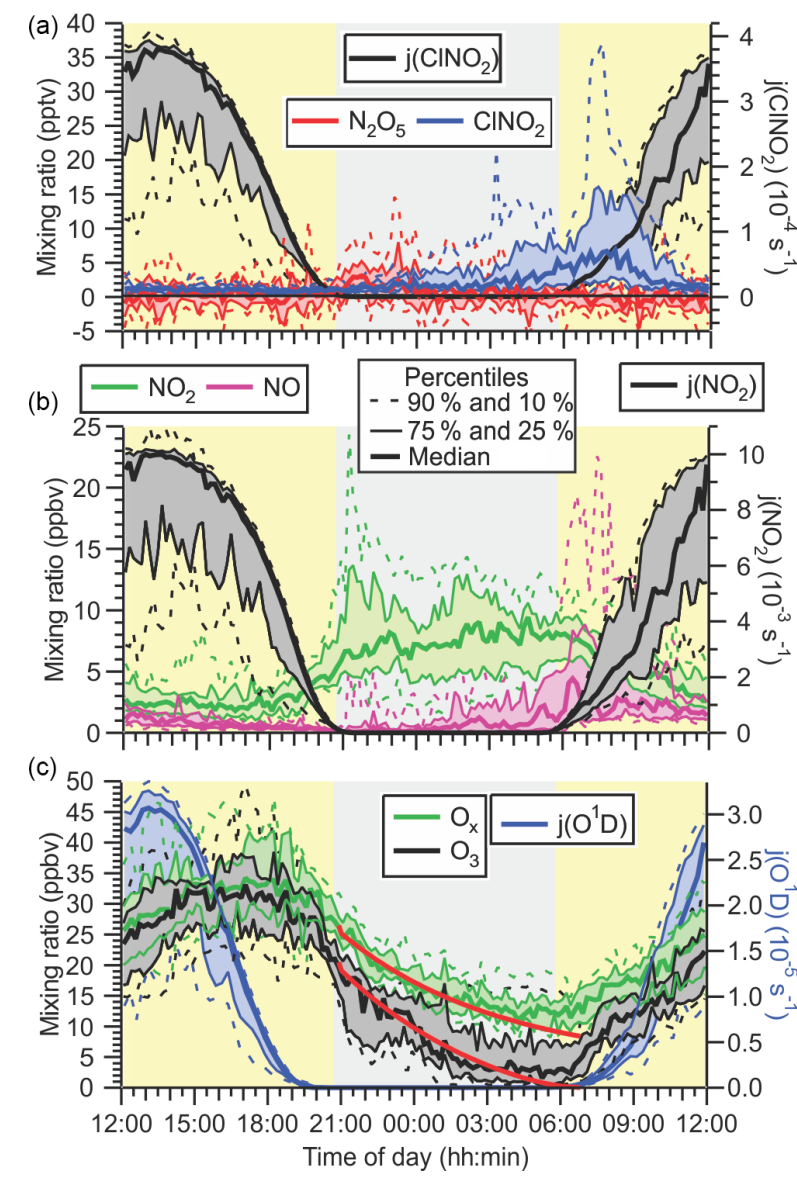

Figure 4. (a) Diurnal variation of $\mathrm{ClNO}_{2}$ and $\mathrm{N}_{2} \mathrm{O}_{5}$ mixing ratios (left axis) and $\mathrm{ClNO}_{2}$ photolysis frequencies (right axis). (b) Diurnal profiles of $\mathrm{NO}$ and $\mathrm{NO}_{2}$ (left axis) and $\mathrm{NO}_{2}$ photolysis frequency (right axis). (c) Diurnal profiles of $\mathrm{O}_{3}$ and $\mathrm{O}_{x}=\mathrm{O}_{3}+\mathrm{NO}_{2}$ (left axis) and $\mathrm{O}_{3} \rightarrow \mathrm{O}\left({ }^{1} \mathrm{D}\right)$ photolysis frequency (right axis). The superimposed lines shown in red are results from a simple box model (see text).

period leading up to sunrise, there was fog (virtually ensuring the absence of $\mathrm{N}_{2} \mathrm{O}_{5}$ ), and $\mathrm{ClNO}_{2}$ mixing ratios were $<5$ pptv. The fog then dissipated at sunrise. One hour later, $\mathrm{ClNO}_{2}$ mixing ratios increased to $>40 \mathrm{pptv}$. Similar events (though with more modest $\mathrm{ClNO}_{2}$ increases) were observed on the mornings of $22,23,25,27,28,30,31$ July and $1 \mathrm{Au}-$ gust. Two of these (23 and 27 July) overlapped with brief fog events.

Qualitatively similar $\mathrm{ClNO}_{2}$ morning peaks have been observed at other ground sites and were rationalized by vertical mixing (Tham et al., 2016; Bannan et al., 2015; Faxon et al., 2015).

In the period after the $\mathrm{ClNO}_{2}$ morning peak after $\sim 09: 00$, $\mathrm{ClNO}_{2}$ mixing ratios decreased, coinciding with the increasing $\mathrm{ClNO}_{2}$ photolysis rate. Box model simulations (see Supplement) indicate that the decay of $\mathrm{ClNO}_{2}$ (after 09:00) was consistent with its destruction by photolysis.
There were two exceptions: the mornings of 27 July and 2 August, when the decay of $\mathrm{ClNO}_{2}$ concentration occurred at a rate faster than its photolysis. On 27 July, fog was not observed until 08:00, at which time the $\mathrm{ClNO}_{2}$ mixing ratio rapidly decreased because of dissolution and/or an air mass shift to one with a different chemical history. On 2 August, the campaign maximum of $97 \mathrm{pptv}$ was observed at 04:40 prior to sunrise, followed by a sharp decline. Hourly logs indicated scattered showers at 06:00.

\subsection{5 $\mathrm{PM}_{1}$ size distribution and composition measurements}

The time series of $\mathrm{PM}_{1}$ surface area density $\left(S_{\mathrm{A}}\right)$ observed by the SMPS is shown in Fig. 5a. The aerosol loadings were modest: the average (median) surface area density was 128 (104) $\mu^{2} \mathrm{~cm}^{-3}$ and ranged from extremes of 26 to $618 \mu \mathrm{m}^{2} \mathrm{~cm}^{-3}$. The size distribution data show that bulk of the surface area (i.e., the mean diameter $\left.\left(\bar{D}_{\mathrm{s}}\right)\right)$ is in the range of 200 to $300 \mathrm{~nm}$, such that most of the area of the accumulation mode was captured. However, the surface area calculations do not include contributions from larger diameter particles which were not quantified. Shown on the right-hand side of Fig. 5a is the rate coefficient for heterogeneous uptake of $\mathrm{N}_{2} \mathrm{O}_{5}, k_{N_{2} O_{5}}$, calculated using Eq. (1).

$k_{\mathrm{N}_{2} \mathrm{O}_{5}}=\frac{1}{4} \gamma \bar{c} S_{\mathrm{A}}$

Here, $\gamma$ and $\bar{c}$ are the uptake probability and the mean molecular speed of $\mathrm{N}_{2} \mathrm{O}_{5}$, respectively. Equation (1) is valid for uptake on small, submicron aerosol as it neglects gas-phase diffusion limitations (Davidovits et al., 2006). For this calculation, a $\gamma$ value of 0.025 was assumed. The average $( \pm 1$ standard deviation) of $k_{\mathrm{N}_{2} \mathrm{O}_{5}}$ was $(2 \pm 1) \times 10^{-4} \mathrm{~s}^{-1}$.

The ACSM submicron aerosol composition data are shown as a time series in Fig. $5 b$ and as a function of time of day in Fig. 6. Consistent with the size distributions, mass loadings were also modest overall (average $2.3 \mu \mathrm{g} \mathrm{m}^{-3}$ ). The ACSM factor analysis identified oxygenated organic aerosol (OOA) as the largest mass fraction of the non-refractory aerosol (average \pm standard deviation $1.4 \pm 1.2 \mu \mathrm{g} \mathrm{m}^{-3}, 63.3 \%$ of the total aerosol mass measured by the ACSM). Hydrocarbon-like organic aerosol (HOA) associated with primary emissions was a minor component (average $0.03 \mu \mathrm{g} \mathrm{m}^{-3}, 1.1 \%$ ) but occasionally enhanced in plumes (maximum $8.3 \mu \mathrm{g} \mathrm{m}^{-3}$ ). The OOA did not exhibit a discernible diurnal profile (Fig. 6a), which is consistent with the modest photochemistry at this site as judged from the modest peak $\mathrm{O}_{3}$ levels observed. The inorganic mass fraction was dominated by nitrate $\left(0.47 \pm 0.40 \mu \mathrm{g} \mathrm{m}^{-3}\right.$, $20.7 \%)$. The second most abundant inorganic component was ammonium $\left(0.2 \pm 1.4 \mu \mathrm{g} \mathrm{m}^{-3}, 8.8 \%\right)$ followed by sulfate $\left(0.15 \pm 0.15 \mu \mathrm{g} \mathrm{m}^{-3}, 6.8 \%\right)$. The data are of similar magnitude as aerosol mass spectrometry (AMS) data collected at nearby Langley as part of Pacific 2001 (Boudries 

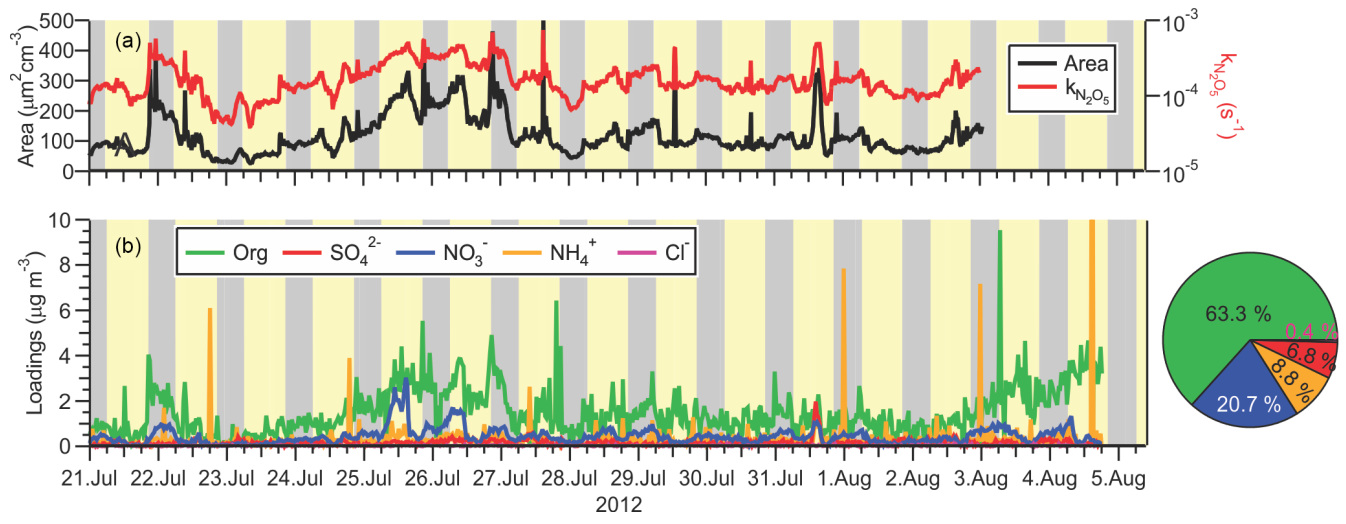

Figure 5. Time series of (a) submicron surface area density measured by the TSI 3034 scanning mobility particle sizer (left-hand side) and calculate heterogeneous $\mathrm{N}_{2} \mathrm{O}_{5}$ uptake rate coefficient assuming $\gamma=0.025$ (right-hand side), and (b) ' non-refractory submicron aerosol species measured by ACSM. The average total loading was $2.3 \mu \mathrm{g} \mathrm{m}^{-3}$. The pie chart shows the average campaign composition.

et al., 2004); then, organics were also the largest component (average of $1.6 \mu \mathrm{g} \mathrm{m}^{-3}, 49 \%$ ), though sulfate and ammonium mass loadings were larger $\left(0.88\right.$ and $0.44 \mu \mathrm{g} \mathrm{m}^{-3}$; 25 and $14 \%$, respectively) and nitrate mass loadings smaller $\left(0.38 \mu \mathrm{g} \mathrm{m}^{-3}, 12 \%\right)$.

The neutralization ratio, $\mathrm{NR} \approx\left[\mathrm{NH}_{4}^{+}\right]:\left(\left[\mathrm{NO}_{3}^{-}\right]+\right.$ $2\left[\mathrm{SO}_{4}^{2-}\right]$ ) (Zhang et al., 2007), where the square brackets denote molar concentrations (calculated from the mass concentrations reported by the ACSM by dividing by the appropriate molecular weights), was 1.19 (median value). The high $\mathrm{NH}_{3}$ content is qualitatively consistent with the non-quantitative data collected by Metro Vancouver (using a Thermo Scientific $17 \mathrm{i} \mathrm{NH} / 3 / \mathrm{NO} / \mathrm{NO}_{2} / \mathrm{NO}_{\mathrm{x}}$ analyzer), which showed large concentrations of gas-phase $\mathrm{NH}_{3}$ (Fig. S1).

The ACSM software also reported non-refractory chloride with an average ( \pm 1 standard deviation) concentration of $0.01 \pm 0.03 \mu \mathrm{g} \mathrm{m}^{-3}$, though it is unclear whether this signal was real as it did not vary over the course of the campaign and was below the stated ACSM detection of limit of $0.2 \mu \mathrm{g} \mathrm{m}^{-3}$ (Ng et al., 2011).

Aerosol nitrate exhibited a clear diurnal profile with higher concentrations at night (Fig. 6b). In particular, the amount of aerosol nitrate increased at the beginning of the night, when the nocturnal $\mathrm{NO}_{3}$ production rates were greatest.

Previous AMS measurements in Vancouver during the month of August as part of Pacific 2001 reported a slightly higher total mass loadings of $7.0 \mu \mathrm{g} \mathrm{m}^{-3}$ that included a greater HOA component $\left(2.4 \mu \mathrm{g} \mathrm{m}^{-3}, 34 \%\right)$ and a smaller nitrate fraction $\left(0.6 \mu \mathrm{g} \mathrm{m}^{-3}, 8.5 \%\right)$ (Alfarra et al., 2004; Jimenez et al., 2009) than observed here. The lower HOA in this data set is likely a result of tighter emission controls implemented since the earlier study, a topic outside the scope of this paper.

\subsubsection{Hydrocarbon measurements}

Mixing ratios of hydrocarbons were quantified during daytime and during the nights of 2-3 and 3-4 August. A portion of the hydrocarbon data is shown in Fig. 7a. Mixing ratios were generally smaller during the day than during night, due to the larger daytime mixing heights. On the nights of $2 / 3$ and 3/4 August, $\mathrm{N}_{2} \mathrm{O}_{5}$ was not detected, consistent with low $P\left(\mathrm{NO}_{3}\right)$ values as $\mathrm{O}_{3}$ mixing ratios approached zero (Fig. 3). At the same time, there were strong $\mathrm{NO}_{3}$ sinks present: mixing ratios of $\alpha$-pinene and limonene (left-hand axis) increased throughout the night, as thermal emissions continued into the shallow NBL. In contrast, mixing ratios of isoprene, whose emissions are driven by photosynthesis (Hewitt et al., 2011; Guenther et al., 1995), increased at the beginning of the nights and then decreased as isoprene was removed by oxidation with $\mathrm{O}_{3}$ and $\mathrm{NO}_{3}$ and by transport. Throughout both nights, the site was also influenced by anthropogenic hydrocarbons (e.g., isooctane and toluene, righthand axis). Because synoptic conditions as judged from local wind speed and direction (Fig. 3d) were similar on most of the other nights when hydrocarbons were not quantified, the data shown in Fig. 7a were likely representative for much of the campaign.

The VOC data were not sufficiently comprehensive to allow an accurate determination of the $\mathrm{NO}_{3}$ loss frequency

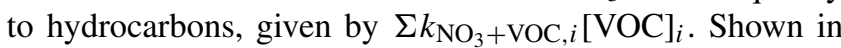
Fig. $7 \mathrm{~b}$ is the loss frequency of $\mathrm{NO}_{3}$ to isoprene, calculated by multiplying its concentration with the $\mathrm{NO}_{3}$ rate coefficient taken from Seinfeld and Pandis (2006). Loss of $\mathrm{NO}_{3}$ to isoprene was a small sink compared to its loss to NO via Reaction (R3) and $\mathrm{NO}_{3}$ photolysis (Reaction R4) but was approximately on par with its indirect loss, i.e., the heterogeneous uptake of $\mathrm{N}_{2} \mathrm{O}_{5}$. 

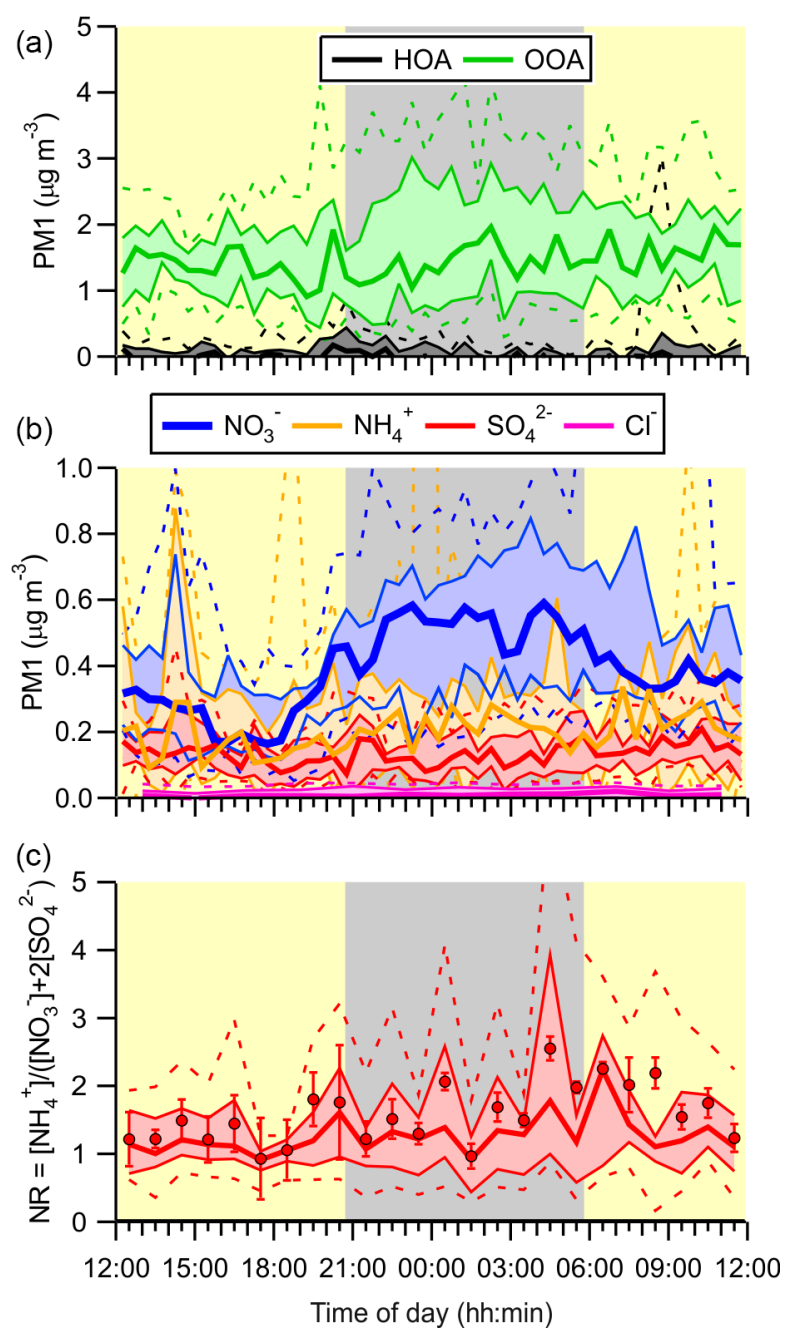

Figure 6. Diurnal averages of submicron $\left(\mathrm{PM}_{1}\right)$ ACSM data. (a) Organic aerosol displayed as hydrocarbon-like organic aerosol (HOA) and oxygenated organic aerosol (OOA) factors. (b) Inorganic aerosol fractions. (c) Neutralization ratio (NR).

\subsection{Analysis}

\subsubsection{Box model simulations of the nocturnal $\mathrm{O}_{3}$ and $\mathrm{O}_{x}$ loss in the NBL}

In initial simulations, the $\mathrm{O}_{3}$ and $\mathrm{NO}_{2}$ deposition rates were tuned until the median nocturnal $\mathrm{O}_{x}$ loss was reproduced. An $\mathrm{O}_{3}$ dry deposition rate of $4 \times 10^{-5} \mathrm{~s}^{-1}$ produced a simulation that reasonably matched the observations (Fig. S2). The magnitude of this rate corresponds to a NBL height of $50 \mathrm{~m}$, the same mixing height that was frequently observed in balloon vertical profiles reported by Pisano et al. (1997). However, since wind speeds at night were low during the study (median $3.6 \mathrm{~km} \mathrm{~h}^{-1}$ ), the aerodynamic resistance to vertical transport was likely elevated due to reduced turbulence. It is therefore conceivable that the $\mathrm{O}_{3}$ dry deposition velocity was in actu-
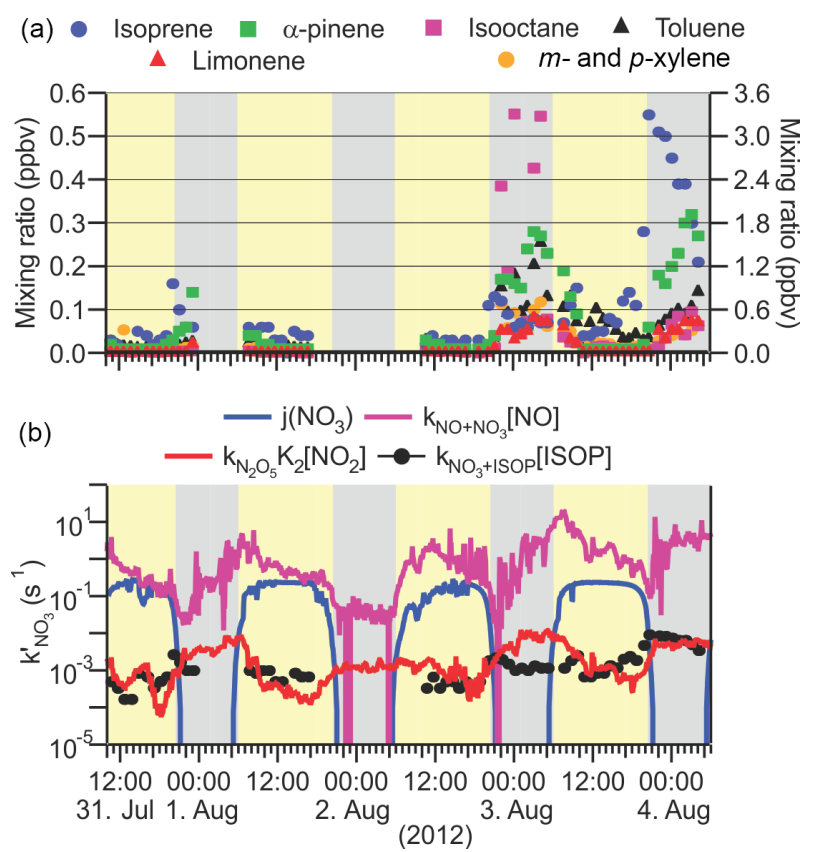

Figure 7. (a) Time series of selected VOC mixing ratios observed on the nights of $2 / 3$ and 3/4 August, 2012. Biogenic VOCs (isoprene, $\alpha$-pinene and limonene) are shown on the left-hand axis, and anthropogenic VOCs (isooctane, toluene and $m$ - and $p$-xylene) on the right-hand axis. The $\alpha$-pinene and limonene measurements are semi-quantitative. (b) Time series of $\mathrm{NO}_{3}$ loss-rate coefficients. ISOP $=$ isoprene.

ality smaller than the values taken from Lin et al. (2010) and the mixing height was greater than $50 \mathrm{~m}$.

Modelling studies have assumed $\mathrm{N}_{2} \mathrm{O}_{5}$ and $\mathrm{NO}_{3}$ deposition velocities of up to $2 \mathrm{~cm} \mathrm{~s}^{-1}$ in urban areas (Sander and Crutzen, 1996); adopting this value allows the dry deposition rate constants of $\mathrm{N}_{2} \mathrm{O}_{5}$ and $\mathrm{NO}_{3}$ to be estimated at $\sim 4 \times 10^{-4} \mathrm{~s}^{-1}$, which is on par with the estimated heterogeneous uptake rate constant of $\mathrm{N}_{2} \mathrm{O}_{5}$ on submicron aerosol.

Next, the generic biogenic VOC was added. For this, a biogenic hydrocarbon abundance of $1 \mathrm{ppbv}$ at sunset (mostly isoprene - see Fig. 7) and a (monoterpene) emission rate of $3 \times 10^{5}$ molecules $\mathrm{cm}^{-3} \mathrm{~s}^{-1}$ based on the crop emission factor given by Guenther et al. (2012) into a $50 \mathrm{~m}$ deep NBL were assumed. This assumed flux gives a similar emission rate as the $0.3 \mathrm{ppbv}$ increase over a $6 \mathrm{~h}$ period observed on 3-4 August (Fig. 7). The addition of this biogenic VOC only had a marginal effect on $\mathrm{O}_{x}$ (Fig. S3).

The simulations presented in Fig. S2 underpredict the observed loss of $\mathrm{O}_{3}$, necessitating the addition of an NO source that results in selective removal of $\mathrm{O}_{3}$ while preserving $\mathrm{O}_{x}$. Since automobiles are the largest $\mathrm{NO}_{x}$ source in the region, a constant emission source of $95 \% \mathrm{NO}$ and $5 \% \mathrm{NO}_{2}$ (Wild et al., 2017) was added and its magnitude varied. The $\mathrm{NO}_{x}$ source strength necessary to reproduce the median $\mathrm{O}_{3}$ loss was $\sim 1.1 \mathrm{ppbvh}^{-1}$. The simulation results using these pa- 
rameters are superimposed (in red) in Fig. 4c. There is reasonable agreement between the simulations and observations of $\mathrm{O}_{x}$ and $\mathrm{O}_{3}$ until $\sim$ 03:00 (and between simulation and observation of NO, Fig. S4). This shows that the nocturnal $\mathrm{O}_{3}$ and $\mathrm{O}_{x}$ loss can be rationalized without active $\mathrm{NO}_{3}$ and $\mathrm{N}_{2} \mathrm{O}_{5}$ chemistry and suggests that $\mathrm{NO}_{3}, \mathrm{~N}_{2} \mathrm{O}_{5}$, and $\mathrm{ClNO}_{2}$ did not contribute significantly to $\mathrm{O}_{x}$ and $\mathrm{O}_{3}$ loss in the NBL.

\subsubsection{Metrics of nocturnal nitrogen oxide chemistry: $P\left(\mathrm{NO}_{3}\right), \phi '\left(\mathrm{ClNO}_{2}\right)$, and $\tau\left(\mathrm{N}_{2} \mathrm{O}_{5}\right)$}

Nocturnal $\mathrm{N}_{2} \mathrm{O}_{5}$ chemistry was analyzed using several common metrics: the rate of $\mathrm{NO}_{3}$ production by Reaction $(\mathrm{R} 1)$, $P\left(\mathrm{NO}_{3}\right)=k_{1}\left[\mathrm{NO}_{2}\right]\left[\mathrm{O}_{3}\right]$, the yield of $\mathrm{ClNO}_{2}$ relative to the total amount of $\mathrm{NO}_{3}$ formed at night, $\phi^{\prime}\left(\mathrm{ClNO}_{2}\right)$, and the steady-state lifetime of $\mathrm{N}_{2} \mathrm{O}_{5}, \tau\left(\mathrm{N}_{2} \mathrm{O}_{5}\right)$.

The time-of-day dependence of $P\left(\mathrm{NO}_{3}\right)$ is shown in Fig. 8a. The $\mathrm{NO}_{3}$ production rates were small (median values $<0.3 \mathrm{ppbv} \mathrm{h}^{-1}$ ) and were larger during the day than at night due to the low $\mathrm{O}_{3}$ mixing ratios. After midnight, for example, the median $P\left(\mathrm{NO}_{3}\right)$ was $(55 \pm 23) \mathrm{pptv} \mathrm{h}^{-1}$. These are very modest $\mathrm{NO}_{3}$ production rates for a site influenced by urban emissions. In a recent study on a mountain top in Hong Kong, for instance, $P\left(\mathrm{NO}_{3}\right)$ in excess of $1 \mathrm{ppbvh} \mathrm{h}^{-1}$ was observed in polluted air (Brown et al., 2016).

The median integrated nocturnal $\mathrm{NO}_{3}$ production over the course of the night was 940 pptv (Fig. 8a, right-hand axis), of which 600 pptv was produced before midnight. The amount of $\mathrm{ClNO}_{2}$ produced relative to this amount, $\phi^{\prime}\left(\mathrm{ClNO}_{2}\right)$, was very small (median $0.17 \%$, maximum $5.4 \%$ on the morning of 2 August) and considerably less than reported by our group for Calgary (median 1.0\%) (Mielke et al., 2016) and Pasadena, CA (median 12\%) (Mielke et al., 2013).

A frequently calculated metric of nighttime nitrogen oxide chemistry is the steady-state lifetimes of $\mathrm{NO}_{3}$ and $\mathrm{N}_{2} \mathrm{O}_{5}$, $\tau\left(\mathrm{NO}_{3}\right)$, and $\tau\left(\mathrm{N}_{2} \mathrm{O}_{5}\right)$ (Aldener et al., 2006; Heintz et al., 1996). The latter is calculated from (Brown et al., 2003; Brown and Stutz, 2012)

$$
\begin{aligned}
\tau\left(\mathrm{N}_{2} \mathrm{O}_{5}\right) & =\frac{\left[\mathrm{N}_{2} \mathrm{O}_{5}\right]}{P\left(\mathrm{NO}_{3}\right)}=\frac{\left[\mathrm{N}_{2} \mathrm{O}_{5}\right]}{k_{1}\left[\mathrm{NO}_{2}\right]\left[\mathrm{O}_{3}\right]} \\
& \approx\left(k_{\mathrm{N}_{2} \mathrm{O}_{5}}+\frac{k_{\mathrm{NO}_{3}}}{\mathrm{~K}_{2}\left[\mathrm{NO}_{2}\right]}\right)^{-1} .
\end{aligned}
$$

Here, $k_{\mathrm{N}_{2} \mathrm{O}_{5}}$ and $k_{\mathrm{NO}_{3}}$ are the pseudo-first-order loss-rate coefficients of $\mathrm{N}_{2} \mathrm{O}_{5}$ and $\mathrm{NO}_{3}$, respectively, and $\mathrm{K}_{2}$ is the equilibrium constant for equilibrium (Reaction R2).

A central assumption in Reaction (R2) is that $\mathrm{NO}_{3}, \mathrm{NO}_{2}$, and $\mathrm{N}_{2} \mathrm{O}_{5}$ more rapidly equilibrate than $\mathrm{NO}_{3}$ is formed and either $\mathrm{NO}_{3}$ or $\mathrm{N}_{2} \mathrm{O}_{5}$ is destroyed; i.e., $\mathrm{NO}_{3}+\mathrm{N}_{2} \mathrm{O}_{5}$ are assumed to be in steady state with respect to production and loss. Brown et al. (2003) outlined potential pitfalls concerning the validity of the steady-state approximation and recommended that box model simulations are carried out to evaluate if a steady state in $\mathrm{N}_{2} \mathrm{O}_{5}$ can be assumed. Using the median nocturnal $\mathrm{NO}_{2}$ and $\mathrm{O}_{3}$ mixing ratios of $7.5 \mathrm{ppbv}$ and 18 to $5.0 \mathrm{ppbv}$, respectively, a temperature of $286 \mathrm{~K}$, and assumed $\mathrm{N}_{2} \mathrm{O}_{5}$ and $\mathrm{NO}_{3}$ pseudo-first-order loss frequencies of $1 \times 10^{-3} \mathrm{~s}^{-1}$ and between $1 \times 10^{-2} \mathrm{~s}^{-1}$ and $0 \mathrm{~s}^{-1}$, the time to achieve steady state in $\mathrm{N}_{2} \mathrm{O}_{5}$ is 70 min or less (see Supplement). Thus, the steady-state assumption is reasonable for this data set.

A key parameter in Eq. (2) is the strongly temperaturedependent equilibrium constant $\mathrm{K}_{2}$ (Osthoff et al., 2007). At night, the air temperatures during this study were quite warm (median nocturnal minimum of $+13^{\circ} \mathrm{C}$ ) and did not vary a lot between nights (Fig. 8b). The warm temperatures shift equilibrium (Reaction R2) away from $\mathrm{N}_{2} \mathrm{O}_{5}$ and towards $\mathrm{NO}_{3}$ and $\mathrm{NO}_{2}$, making losses via $\mathrm{NO}_{3}$ (Reactions R3-R4, R7) more competitive with the losses of $\mathrm{N}_{2} \mathrm{O}_{5}$ (that produce $\left.\mathrm{ClNO}_{2} ; R\right)$, i.e., the $\frac{k_{\mathrm{NO}_{3}}}{\mathrm{~K}_{2}\left[\mathrm{NO}_{2}\right]}$ term in Eq. (11) becomes large relative to $k_{\mathrm{N}_{2} \mathrm{O}_{5}}$. In contrast, the relatively high $\mathrm{NO}_{2}$ mixing ratios (median value $7.5 \pm 0.8 \mathrm{ppbv}$ ) shift the equilibrium towards $\mathrm{N}_{2} \mathrm{O}_{5}$. Thus, in spite of the relatively warm temperatures, the $\mathrm{N}_{2} \mathrm{O}_{5}: \mathrm{NO}_{3}$ equilibrium ratios were large on aggregate ( $>15$; Fig. 8b), enabling $\mathrm{ClNO}_{2}$ formation via Reaction (R5).

The steady-state lifetime of $\mathrm{N}_{2} \mathrm{O}_{5}, \tau\left(\mathrm{N}_{2} \mathrm{O}_{5}\right)$, is shown as a diurnal average in Fig. 8c. The median $\tau\left(\mathrm{N}_{2} \mathrm{O}_{5}\right)$ at night was short ( $\sim 1 \mathrm{~min})$, and the 90th percentile peaked at a modest 7.6 min at sunrise, considerably shorter than observed above the NBL (Brown et al., 2006b) and at other ground sites (Wood et al., 2005; Crowley et al., 2010; Brown et al., 2016)

Superimposed on the right-hand side of Figure $8 \mathrm{C}$ are upper limits to the steady-state lifetime of $\mathrm{N}_{2} \mathrm{O}_{5}$, calculated using the sum of pseudo-first-order rate coefficients for the titration of $\mathrm{NO}_{3}$ by $\mathrm{NO}\left(\mathrm{k}_{3}[\mathrm{NO}]\right.$, Reaction R3), $\mathrm{NO}_{3}$ photolysis $\left(\mathrm{j}\left(\mathrm{NO}_{3}\right)\right.$, Reaction $\left.\mathrm{R} 4\right)$, and $\mathrm{NO}_{3}$ dry deposition $\left(k_{\text {dep }}\left(\mathrm{NO}_{3}\right)\right.$ ), all divided by the $\mathrm{N}_{2} \mathrm{O}_{5}$ over $\mathrm{NO}_{3}$ ratio at equilibrium given by $\mathrm{K}_{2} \mathrm{NO}_{2}$ (Fig. 8b), plus the pseudofirst-order rate coefficient for $\mathrm{N}_{2} \mathrm{O}_{5}$ heterogeneous uptake $\left(k_{\text {het }}\left(\mathrm{N}_{2} \mathrm{O}_{5}\right)\right.$, Eq. 1) plus $\mathrm{N}_{2} \mathrm{O}_{5}$ dry deposition $\left(k_{\text {dep }}\left(\mathrm{N}_{2} \mathrm{O}_{5}\right)\right)$.

$$
\begin{aligned}
\tau\left(\mathrm{N}_{2} \mathrm{O}_{5}\right) & =\left(\frac{k_{\mathrm{NO}_{3}}}{K_{2}\left[\mathrm{NO}_{2}\right]}+k_{\mathrm{N}_{2} \mathrm{O}_{5}}\right)^{-1} \\
& <\left(\frac{k_{3}[\mathrm{NO}]+j\left(\mathrm{NO}_{3}\right)+k_{\text {dep }}\left(\mathrm{NO}_{3}\right)}{K_{2}\left[\mathrm{NO}_{2}\right]}\right. \\
& \left.+k_{\text {het }}\left(\mathrm{N}_{2} \mathrm{O}_{5}\right)+k_{\text {dep }}\left(\mathrm{N}_{2} \mathrm{O}_{5}\right)\right)^{-1}
\end{aligned}
$$

The dry deposition rate constants were set to $4 \times 10^{-4} \mathrm{~s}^{-1}$ (see Sect. 3.2.1), which likely overestimates dry deposition during the day due to higher mixing heights; however, the error this introduces is negligible compared to the large daytime sinks such as $\mathrm{NO}_{3}$ photolysis and its reaction with NO. Missing from Eq. (3) are losses of $\mathrm{NO}_{3}$ to hydrocarbons (which were omitted because of the poor VOC data coverage) and terms for $\mathrm{NO}_{3}$ and $\mathrm{N}_{2} \mathrm{O}_{5}$ wet (i.e., on cloud and rain droplets) deposition. Periods affected by precipitation or fog (shown in Fig. 3d) were hence excluded from the calcu- 

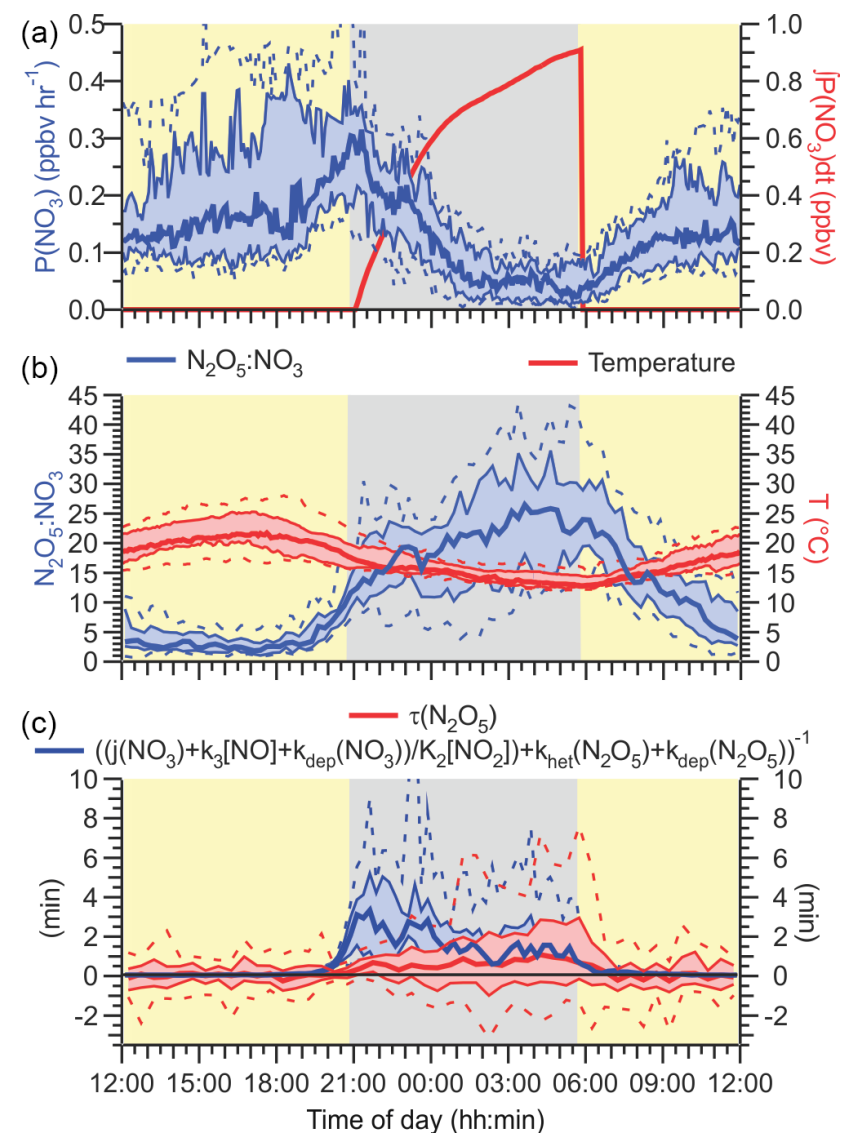

Figure 8. (a) $\mathrm{NO}_{3}$ production rate $P\left(\mathrm{NO}_{3}\right)=\mathrm{k}_{1}\left[\mathrm{NO}_{2}\right]\left[\mathrm{O}_{3}\right]$ as a function of time of day. The red line is the total amount $\mathrm{NO}_{3}$ generated since sunset, $P\left(\mathrm{NO}_{3}\right) \mathrm{d} t$. (b) Equilibrium ratio of $\mathrm{N}_{2} \mathrm{O}_{5}$ to $\mathrm{NO}_{3}$ calculated by multiplying the temperature-dependent equilibrium constant, $\mathrm{K}_{2}$, with the $\mathrm{NO}_{2}$ concentration, [ $\mathrm{NO}_{2}$ ] (left axis), and air temperature (right axis). (c) Steady-state lifetime of $\mathrm{N}_{2} \mathrm{O}_{5}$ (left axis) and upper limits calculated using Eq. (3) (right axis) as functions of time of day.

lation. Estimates of how loss of $\mathrm{NO}_{3}$ to VOCs could affect the lifetime of $\mathrm{N}_{2} \mathrm{O}_{5}$ are given in the Supplement.

The median "observed" $\tau\left(\mathrm{N}_{2} \mathrm{O}_{5}\right)$ is below or equal to the upper limit calculation with Eq. (3) during both night and day. The largest discrepancy is observed at the beginning of the night, when oxidation of (unsaturated) hydrocarbons by $\mathrm{NO}_{3}$ (Reaction R7) was likely most significant due to the presence of isoprene and other biogenic VOCs. Indeed, if the $\Sigma \mathrm{k}_{\mathrm{NO}_{3}+\mathrm{VOC}, i}[\mathrm{VOC}]_{i}$ is assumed to be $0.11 \mathrm{~s}^{-1}$ (average nocturnal $\mathrm{NO}_{3}$ loss frequency reported by Liebmann et al., 2018), the gap between observed and calculated $\mathrm{N}_{2} \mathrm{O}_{5}$ lifetime between sunset and midnight closes (Fig. S8). However, this is also the time when the steady-state approximation is most likely invalid.

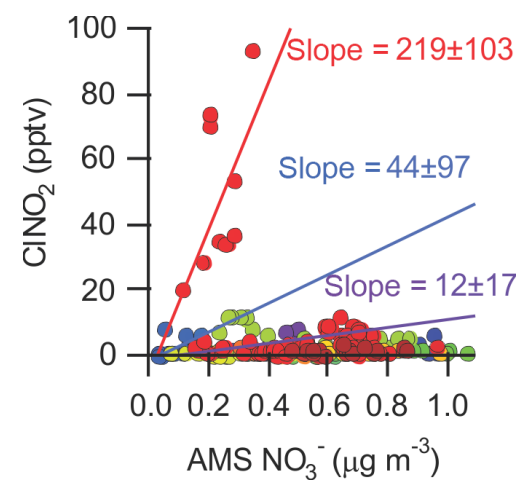

Figure 9. Scatter plot of $\mathrm{ClNO}_{2}$ mixing ratios with submicron $\left(\mathrm{PM}_{1}\right)$ ACSM NO $\mathrm{N}_{3}^{-}$data. The slopes were calculated for three periods: 2 August, 01:25-04:55 (red dots; slope $=219 \pm 103 ; \varphi=$ 0.72), 23 July, 03:00-04:25 (blue dots slope $=44 \pm 97 ; \varphi=0.21$ ), and 21 July, 02:25-05:20 (purple dots slope $=12 \pm 17 ; \varphi=0.06$ ).

\subsubsection{Heterogeneous conversion of $\mathrm{N}_{2} \mathrm{O}_{5}$ to $\mathrm{ClNO}_{2}$ on the night of 1/2 August}

Phillips et al. (2016) recently applied several methods to estimate the $\mathrm{N}_{2} \mathrm{O}_{5}$ uptake parameter $(\gamma)$ and yield of $\mathrm{ClNO}_{2}$ $(\varphi)$ from ambient measurements of $\mathrm{NO}_{3}, \mathrm{~N}_{2} \mathrm{O}_{5}, \mathrm{ClNO}_{2}$, and aerosol nitrate. One of these methods uses the covariance of $\mathrm{ClNO}_{2}$ and aerosol nitrate production rates, $P\left(\mathrm{NO}_{3}^{-}\right)$and $P\left(\mathrm{ClNO}_{2}\right)$ :

$$
\begin{aligned}
& \varphi=2\left(P\left(\mathrm{NO}_{3}^{-}\right) / P\left(\mathrm{ClNO}_{2}\right)+1\right)^{-1} \\
& \gamma=2\left(P\left(\mathrm{NO}_{3}^{-}\right)+P\left(\mathrm{ClNO}_{2}\right)\right) /\left(c S_{\mathrm{A}}\left[\mathrm{N}_{2} \mathrm{O}_{5}\right]\right) .
\end{aligned}
$$

In the above equations, $c$ is the mean molecular speed of $\mathrm{N}_{2} \mathrm{O}_{5}\left(\approx 237 \mathrm{~m} \mathrm{~s}^{-1}\right)$. The use of Eqs. (4)-(5) assumes that the relevant properties of the air mass are conserved (i.e., identical upwind of and at the measurement location and affected identically by air masses mixing), that losses of measured species are not significant, that the efficiency of $\mathrm{N}_{2} \mathrm{O}_{5}$ uptake and production of $\mathrm{ClNO}_{2}$ and $\mathrm{NO}_{3}^{-}$is independent of particle size, and that partitioning of $\mathrm{HNO}_{3}(\mathrm{~g})$ and aerosol nitrate between the gas and particle phases does not occur (Phillips et al., 2016). It is assumed further that production of nitrate from $\mathrm{N}_{2} \mathrm{O}_{5}$ uptake on refractory aerosol (that the ACSM does not quantify) is minimal.

In this data set, $\mathrm{ClNO}_{2}$ and non-refractory $\mathrm{PM}_{1}$ nitrate rarely covaried (Fig. 9); the only instance showing a modest correlation $(r=0.66)$ is the time period prior to sunrise of 2 August (shown as red dots in Fig. 9).

The night of 1-2 August exhibited the highest nocturnal nitrogen oxide concentrations for the entire campaign. Winds were initially from the NW and relatively light $\left(4.8 \pm 0.7 \mathrm{~km} \mathrm{~h}^{-1}\right)$ and after 01:00 picked up in speed (to $8 \pm 1 \mathrm{~km} \mathrm{~h}^{-1}$ ) and shifted to the W. Judging from the HYbrid Single-Particle Lagrangian Integrated Trajectory (HYSPLIT) back trajectories (Stein et al., 2015), the upwind air 
had moved in from the coast, roughly from the direction of the city of Victoria, BC (Odame-Ankrah, 2015).

After sunset at $\sim 21: 00$ local time, $\mathrm{N}_{2} \mathrm{O}_{5}$ levels started increasing and continued to increase until about 01:30 (Fig. 3a). The steady-state $\mathrm{N}_{2} \mathrm{O}_{5}$ lifetime at this time was the highest of the campaign, $\sim 10 \mathrm{~min}$. At 01:20, $\mathrm{ClNO}_{2} \mathrm{mix}-$ ing ratio increased from $20.4 \mathrm{pptv}$ at $01: 25$ to $93.7 \mathrm{pptv}$ at 04:55 and the $\mathrm{PM}_{1}$ content from 0.10 to $0.34 \mu \mathrm{g} \mathrm{m}^{-3}$ (40 to 127 pptv). During this time, $\mathrm{N}_{2} \mathrm{O}_{5}$ mixing ratios and $\mathrm{PM}_{1}$ surface area density were relatively constant, $11 \pm 6 \mathrm{pptv}$ and $67 \pm 4 \mu^{-3} \mathrm{~m}^{-3}$ (average \pm standard deviation), respectively. The combined amount of $\mathrm{N}_{2} \mathrm{O}_{5}, \mathrm{ClNO}_{2}$ and $\mathrm{PM}_{1} \mathrm{NO}_{3}^{-}$produced (172 pptv) is less than the amount of $\mathrm{NO}_{3}$ produced from Reaction (R1) which was 519 pptv during this period.

From Eqs. (4) and (5), a $\mathrm{ClNO}_{2}$ yield of $\varphi=0.7 \pm 0.3$ and an $\mathrm{N}_{2} \mathrm{O}_{5}$ uptake probability of $\gamma=0.15 \pm 0.07$ were calculated for this period. Both of these values are upper limits because production of $\mathrm{ClNO}_{2}$ from uptake of $\mathrm{N}_{2} \mathrm{O}_{5}$ on unquantified supermicron (i.e., $>0.5 \mu \mathrm{m}$ ) or refractory aerosol (which takes place simultaneously) is not accounted for.

A $\gamma$ value of $>0.05$ is greater than can be rationalized from laboratory and field studies (Chang et al., 2011) and is hence unrealistic. This suggests that $\mathrm{ClNO}_{2}$ production took place predominantly on supermicron or refractory aerosol, which likely was comprised of mainly sea-saltderived aerosol (Anlauf et al., 2006). However, if one assumes that "all" of the $\mathrm{ClNO}_{2}$ is produced on supermicron or refractory aerosol such that $P\left(\mathrm{ClNO}_{2}\right)$ on submicron aerosol equals 0 pptv s$^{-1}$ (which is not unreasonable considering the absence of measurable amounts of aerosol chloride in this size fraction; see Sect. 3.1.5), a $\gamma$ value of $0.08 \pm 0.04$ is calculated. This large value suggests very efficient $\mathrm{N}_{2} \mathrm{O}_{5}$ uptake (and conversion to aerosol nitrate) on the non-refractory submicron aerosol that night.

\subsection{Impacts of $\mathrm{ClNO}_{2}$ on radical production}

Photolysis of $\mathrm{ClNO}_{2}$ increases the rates of photochemical $\mathrm{O}_{3}$ production (and hence worsen air quality) by producing $\mathrm{NO}_{2}$ and reactive $\mathrm{Cl}$ atoms (Reaction $\mathrm{R} 6$ ). The amounts of $\mathrm{ClNO}_{2}$ available for photolysis in the morning (median $3.5 \mathrm{pptv}$ at sunrise and 6.8 pptv at 08:00 local time) were too small to have had a measurable impact on local $\mathrm{NO}_{2}$ concentrations (Fig. 3c) but were sufficiently large to, at least occasionally, impact radical budgets.

Figure 10 shows the instantaneous radical production rates of $\mathrm{Cl}$ and $\mathrm{OH}, P(\mathrm{Cl})=j\left(\mathrm{ClNO}_{2}\right) \times\left[\mathrm{ClNO}_{2}\right]$ and $P(\mathrm{OH})$ from reaction of $\mathrm{O}\left({ }^{1} \mathrm{D}\right)+\mathrm{H}_{2} \mathrm{O}$. The latter was calculated from an assumed steady state in $\mathrm{O}\left({ }^{1} \mathrm{D}\right)$ with respect to its production from $\mathrm{O}_{3}$ photolysis and reactions with $\mathrm{N}_{2}, \mathrm{O}_{2}$, and $\mathrm{H}_{2} \mathrm{O}$ as described by Mielke et al. (2016). This analysis does not account for $\mathrm{OH}$ radical production from photolysis of nitrous acid or aldehydes and, hence, overestimates the importance of $\mathrm{Cl}$ radicals.

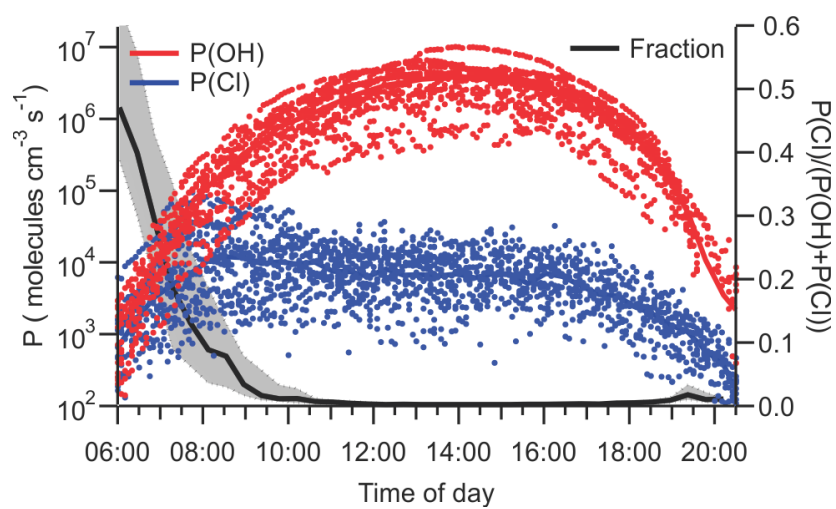

Figure 10. Plots of instantaneous rates of $\mathrm{Cl}$ (blue) and $\mathrm{OH}$ (red) radical production from $\mathrm{ClNO}_{2}$ photolysis and reaction of $\mathrm{O}^{1} \mathrm{D}$, generated from $\mathrm{O}_{3}$ photolysis, with $\mathrm{H}_{2} \mathrm{O}$ and as a function of time of day. The fraction of radicals produced from $\mathrm{ClNO}_{2}$ photolysis is shown in black. The solid line indicates median values, and shaded areas the 75 th and 25 th percentiles.

The largest $P(\mathrm{Cl})$ values were observed on 26 July, 07:45 local time $\left(9.5 \times 10^{4}\right.$ atoms $\left.\mathrm{cm}^{-3} \mathrm{~s}^{-1}\right)$, accounting for $40 \%$ of the total radical production. The largest fraction of radicals produced from $\mathrm{ClNO}_{2}$ photolysis was observed on the same day at 06:35 local time $\left(74 \%, 7.8 \times 10^{3}\right.$ atoms $\left.\mathrm{cm}^{-3} \mathrm{~s}^{-1}\right)$. The photolysis of $\mathrm{ClNO}_{2}$ produces a median value of $6.5 \times 10^{3}$ atoms cm $\mathrm{cm}^{-3} \mathrm{~s}^{-1}$ during daytime, which is negligibly small compared to the median $P(\mathrm{OH})$ of $3.8 \times 10^{6}$ molecules $\mathrm{cm}^{-3} \mathrm{~s}^{-1}$ at noon.

\section{Discussion}

It is now well-established that $\mathrm{ClNO}_{2}$ is an abundant nitrogen oxide in many regions of the troposphere (Table 3 ). The results presented in this paper are atypical in that they show consistently small $\mathrm{ClNO}_{2}$ mixing ratios in spite of close proximity to sources, i.e., in a region where nearby oceanic emissions of sea salt aerosol and $\mathrm{NO}_{x}$ emissions from a megacity combine. In the following, factors contributing to the low $\mathrm{ClNO}_{2}$ mixing ratios observed in this study and broader implications of $\mathrm{ClNO}_{2}$ in the LFV are discussed.

The main reason for the low $\mathrm{ClNO}_{2}$ mixing ratios observed in this work are the low nocturnal mixing ratios of $\mathrm{O}_{3}$ and small $\mathrm{NO}_{3}$ production rate, $P\left(\mathrm{NO}_{3}\right)$, resulting from the stratification of the boundary layer at night and decoupling of the shallow NBL from the NRL. In the following, it is assumed that a boundary layer structure similar to those observed during PACIFIC 93 (Pisano et al., 1997; McKendry et al., 1997; Hayden et al., 1997) also existed on most measurement nights of this study. Once the nocturnal boundary layer formed at sunset, $\mathrm{O}_{3}$ and $\mathrm{O}_{x}$ in the NBL were rapidly (lifetime of $\sim 4 \mathrm{~h}$ ) removed. The box model simulations presented in Sect. 3.2.1 show that this removal can be rationalized by dry deposition and titration of $\mathrm{O}_{3}$ with $\mathrm{NO}$ and 
Table 3. Maximum $\mathrm{ClNO}_{2}$ mixing ratios observed to date.

\begin{tabular}{llrl}
\hline Location & Type & $\begin{array}{r}\text { Maximum } \\
\text { mixing ratio }\end{array}$ & Reference(s) \\
\hline Houston, TX & Off-shore, & $1.2 \mathrm{ppbv}$ & Osthoff et al. (2008) \\
New England & Off-shore & $90 \mathrm{pptv}$ & Kercher et al. (2009) \\
Pasadena, CA & Off-shore & $2.15 \mathrm{ppbv}$ & Riedel et al. (2012a) \\
La Jolla, CA & Coastal & $30 \mathrm{pptv}$ & Kim et al. (2014) \\
Boulder, CO & Continental & $425 \mathrm{pptv}$ & Thornton et al. (2010) \\
Calgary, AB & Continental & $330 \mathrm{pptv}$ & Mielke et al. (2016, 2011) \\
Erie, CO & Continental & $1.3 \mathrm{ppbv}$ & Riedel et al. (2013), Brown et al. (2013) \\
Feldberg, GER & Continental & $800 \mathrm{pptv}$ & Phillips et al. (2012), Phillips et al. (2016) \\
Horsepool, UT & Continental & $500 \mathrm{pptv}$ & Edwards et al. (2014) \\
Pasadena, CA & Coastal, inland & $3.5 \mathrm{ppbv}$ & Mielke et al. (2013) \\
London, UK & Coastal, inland & $724 \mathrm{pptv}$ & Bannan et al. (2015) \\
Hongkong, PRC & Coastal, inland & $2.0 \mathrm{ppbv}$ & Tham et al. (2014) \\
Southeast TX & Coastal, inland & $280 \mathrm{pptv}$ & Faxon et al. (2015) \\
Hongkong, PRC & Coastal, inland & $4.7 \mathrm{ppbv}$ & Wang et al. (2016) \\
North China Plain & Continental & $2.1 \mathrm{ppbv}$ & Tham et al. (2016) \\
North China Plain & Continental & $776 \mathrm{pptv}$ & Wang et al. (2017) \\
Abbotsford, BC & Coastal, inland & $97 \mathrm{pptv}$ & This work \\
\hline
\end{tabular}

biogenic VOCs alone, leaving little room for nitrogen oxide chemistry to destroy $\mathrm{O}_{3}$ or $\mathrm{NO}_{2}$, for example, via heterogeneous formation of $\mathrm{HONO}$, which destroys $\mathrm{NO}_{2}$ (Stutz et al., 2004a; Indarto, 2012), or formation of $\mathrm{N}_{2} \mathrm{O}_{5}$ and subsequent heterogeneous hydrolysis, which consumes two molecules of $\mathrm{NO}_{2}$ and 1 molecule of $\mathrm{O}_{3}$ (Brown et al., 2006a). It is the often complete absence of $\mathrm{O}_{3}$ at night which distinguishes this data set from the other measurement locations for which $\mathrm{ClNO}_{2}$ data have been reported, including continental sites where aerosol chloride is likely less abundant (Table 3).

A compounding factor in this study was the occasional formation of fog and occasional precipitation events. Fog droplets act as a very rapid sink for $\mathrm{NO}_{3}$ and $\mathrm{N}_{2} \mathrm{O}_{5}$ (Osthoff et al., 2006), which shuts down $\mathrm{ClNO}_{2}$ production, and may have also directly contributed episodically to $\mathrm{CINO}_{2}$ losses, for example on the morning of 27 July. Overall, though, the contribution of fog to $\mathrm{ClNO}_{2}$ losses in this data set was minor, as only $5 \%$ of the measurement period was impacted by fog. However, this potential $\mathrm{ClNO}_{2}$ loss mechanism should be investigated further in future lab studies.

The rapid drop of $\mathrm{CINO}_{2}$ mixing ratio at around 06:00 of 2 August is interesting in that it coincided with a very brief precipitation event. Though an air mass shift cannot be ruled out, this coincidence suggests the possibility that scavenging of $\mathrm{ClNO}_{2}$ by rain droplets followed by hydrolysis may be a possible loss pathway. Scavenging of $\mathrm{NO}_{3}, \mathrm{~N}_{2} \mathrm{O}_{5}$, and $\mathrm{CINO}_{2}$ by rain droplets is currently not constrained by laboratory investigations (unlike other gases, such as $\mathrm{SO}_{2}$ or $\mathrm{NH}_{3}$; Hannemann et al., 1995). Similarly to fog, precipitation was not a major factor in this data set as it affected only
$10 \%$ but may be in other locations or seasons that experience higher rainfall amounts.

An important observation is the lack of non-refractory $\mathrm{PM}_{1}$ chloride (Fig. 5b). This suggests that there was limited redistribution of chloride from acidification of sea salt aerosol onto other aerosol surfaces in this data set. Such a redistribution was observed, for example, during the CalNexLA campaign, where the AMS measured a median chloride concentration of $\sim 0.1 \mu^{-3} \mathrm{~m}^{-3}$ on non-refractory aerosol (Mielke et al., 2013). This in turn implies that the submicron aerosol surface did not significantly participate in the production of $\mathrm{ClNO}_{2}$ from $\mathrm{N}_{2} \mathrm{O}_{5}$ uptake in the NBL, broadly consistent with the conclusions in Sect. 3.2.3 and consistent with measurements of water-soluble aerosol components in the LFV during Pacific 2001 (Anlauf et al., 2006) that showed no evidence for chloride redistribution to $\mathrm{PM}_{1}$ from larger particles where aerosol chloride was present.

The low observed $\tau\left(\mathrm{N}_{2} \mathrm{O}_{5}\right)$ is consistent with earlier studies that reported strong vertical gradients in $\tau\left(\mathrm{N}_{2} \mathrm{O}_{5}\right)$ due to elevated near-surface sinks from emissions by plants (i.e., monoterpenes) and automobiles (i.e., NO and butadiene; Curren et al., 2006) that titrate $\mathrm{NO}_{3}$ (Stutz et al., 2004b; Wang et al., 2006; Brown et al., 2007; Young et al., 2012). An emblematic example is the study by Wood et al. (2005) at a ground site east of the San Francisco Bay Area in January 2004: They observed relatively modest $\mathrm{N}_{2} \mathrm{O}_{5}$ mixing ratios of up to $200 \mathrm{pptv}$, corresponding to $\tau\left(\mathrm{N}_{2} \mathrm{O}_{5}\right)<5 \mathrm{~min}$ for the entire study period. Studies for which vertically resolved data were available (e.g., Stutz et al., 2004b; Wang et al., 2006; Brown et al., 2007; Young et al., 2012; Tsai et 
al., 2014) generally showed higher $\mathrm{N}_{2} \mathrm{O}_{5}$ concentrations and hence larger $\tau\left(\mathrm{N}_{2} \mathrm{O}_{5}\right)$ aloft in the NRL than at the surface.

A different scenario likely played out aloft in the NRL, which would exhibit higher $\mathrm{NO}_{3}$ production rates (via Reactions R1) than the surface layer. Assuming levels of $20 \mathrm{ppbv}$ of $\mathrm{O}_{3}$ and $\mathrm{NO}_{2}$ in the NRL (Pisano et al., 1997; McKendry et al., 1997), the $\mathrm{NO}_{3}$ production rate would equal $\sim 1.1 \mathrm{ppbv} \mathrm{h}^{-1}$ in the NRL, roughly on par with values recently reported for Hong Kong, the current record holder for $\mathrm{ClNO}_{2}$ mixing ratios (Brown et al., 2016; Wang et al., 2016). Recent aircraft and tower studies have shown high rates of production of $\mathrm{ClNO}_{2}$ aloft (Riedel et al., 2013; Young et al., 2012), which likely also occurred in this work.

In contrast, the low mixing height of the NBL is conducive to high levels of biogenic hydrocarbons (Sect. 3.1.6). The nocturnal temperatures during this study were quite warm and did not vary a lot between nights (Fig. 8b). Emissions of monoterpenes, which are reactive towards $\mathrm{NO}_{3}$, are driven by a temperature-dependent process from storage tissue within the plants at night (Guenther et al., 1995) and, hence, were likely substantial. Their presence is likely responsible for the difference between the "observed" $\mathrm{N}_{2} \mathrm{O}_{5}$ steady lifetimes, $\tau\left(\mathrm{N}_{2} \mathrm{O}_{5}\right)$, and upper limit calculated using equation (3) before midnight (Figs. 8c and S8). Even if one assumes a relatively large uptake probability of $\gamma=0.025$ and accounts for the large ratios of $\mathrm{N}_{2} \mathrm{O}_{5}: \mathrm{NO}_{3}$, the loss rate of $\mathrm{N}_{2} \mathrm{O}_{5}$ on submicron aerosol was likely small in comparison to losses via $\mathrm{NO}_{3}$ for most of this data set (Fig. 7b). Hence, only a small fraction of the integrated nocturnal $\mathrm{NO}_{3}$ production of 940 pptv resulted in $\mathrm{ClNO}_{2}$ formation at the surface.

Because of the relatively long lifetime of $\mathrm{ClNO}_{2}$, the breakdown of the surface layer and merging of the surface air with the NRL constituted itself as a $\mathrm{ClNO}_{2}$ "morning peak" in a similar manner as what has recently been reported at other locations (Tham et al., 2016; Bannan et al., 2015; Faxon et al., 2015). This morning peak is rationalized by higher net $\mathrm{ClNO}_{2}$ production in the NRL; the breakup of this layer $\sim 2 \mathrm{~h}$ after sunrise then mixes $\mathrm{CINO}_{2}$ down to the surface. Such a vertical mixing process was not seen during CalNex-LA (Young et al., 2012; Tsai et al., 2014) where the NBL was sufficiently deep to prevent complete $\mathrm{O}_{3}$ removal and the $\mathrm{CINO}_{2}$ produced mixed down to the surface at night.

Assuming a $100 \mathrm{~m}$ deep NRL where $\mathrm{ClNO}_{2}$ production takes place, a mixed layer height of $500 \mathrm{~m}$ by 08:00 (Pisano et al., 1997) and negligible destruction of $\mathrm{ClNO}_{2}$ by photolysis (which is reasonable as the lifetime of $\mathrm{ClNO}_{2}$ with respect to photolysis is $>4.6 \mathrm{~h}$ at that time of day), a morning increase in $\mathrm{ClNO}_{2}$ mixing ratio by $40 \mathrm{pptv}$ at the surface as seen on the morning of 26 July suggests a pool of $\mathrm{ClNO}_{2}$ in the NRL at sunrise of $\sim 200$ pptv, likely a modest value considering that the (assumed) $\mathrm{NO}_{3}$ production rate may have integrated to $\sim 9$ ppbv over the course of the night.

The largest nocturnal $\mathrm{ClNO}_{2}$ mixing ratios were observed on 22-23 July and 1-2 August. Both of these nights exhibited high wind speeds and are counterexamples to what was observed on other nights. We speculate that the higher levels of wind shear and turbulence altered the nocturnal boundary layer structure which exhibited a greater degree of vertical mixing and higher $\mathrm{O}_{3}$ concentrations at the surface. Consistent with this interpretation and the notion that an isolated NRL with higher net $\mathrm{ClNO}_{2}$ production was absent on those nights, the mornings of 23 July and 2 August did not show a "morning peak". In contrast, low surface wind speeds were observed on the other nights, facilitating a stable and shallow nocturnal surface layer.

It is conceivable that a land-sea breeze effect transported air from a region closer to the coast that saw higher $\mathrm{ClNO}_{2}$ production than at Abbotsford, i.e., that the $\mathrm{ClNO}_{2}$ morning peaks are generated by horizontal as opposed to vertical transport. Large $\mathrm{NO}_{3}$ mixing ratios have been reported at Saturna Island (McLaren et al., 2010), which strongly suggest that sizeable reservoirs of $\mathrm{ClNO}_{2}$ form offshore at night. However, it is not known how far inland these reservoirs extend. Considering the average wind speed in the morning $\left(6 \mathrm{~km} \mathrm{~h}^{-1}\right)$, distance to the coast $(35 \mathrm{~km})$, and close proximity $(200 \mathrm{~m})$ of the site to the bottom of the polluted NRL with documented high nocturnal pollution levels and early morning down-mixing events, the vertical transport explanation is much more likely correct. Nevertheless, measurements of $\mathrm{ClNO}_{2}$ at a site closer to the coast (e.g., at White Rock) would be beneficial.

Formation of $\mathrm{ClNO}_{2}$ affects air quality through its photolysis which generates $\mathrm{O}_{x}, \mathrm{NO}_{x}$, and reactive $\mathrm{Cl}$ radicals in the morning, leading to higher net photochemical $\mathrm{O}_{3}$ production (Sarwar et al., 2014). In spite of the low levels of $\mathrm{ClNO}_{2}$ observed in this work, the production of radicals from its photodissociation was not always negligible (Fig. 10). Conditions leading to $\mathrm{O}_{3}$ exceedances did not develop during this study. If such conditions had developed, it is highly likely that this radical generation pathway would have played a much greater role.

The data presented here suggest that higher rates of $\mathrm{ClNO}_{2}$ and subsequent radical generation take place routinely in layers aloft, processes that are not directly observable at the surface but whose implications are felt as the ultimate product, $\mathrm{O}_{3}$, is sufficiently long-lived to mix down to the surface (McKendry et al., 1997). Future studies should therefore target the NRL, for example through missed-approaches by aircraft, a blimp, or from a tall tower, especially during episodes of a developing $\mathrm{O}_{3}$ exceedance event and also include composition measurements of refractory aerosol.

\section{Summary and conclusions}

In this paper, we have presented the first measurements of $\mathrm{ClNO}_{2}$ and $\mathrm{N}_{2} \mathrm{O}_{5}$ mixing ratios in the LFV. In spite of the close proximity to $\mathrm{NO}_{x}$ (Greater Vancouver) and sea salt aerosol (the Pacific Ocean) sources, $\mathrm{ClNO}_{2}$ and $\mathrm{N}_{2} \mathrm{O}_{5}$ mixing ratios were small (maximum of 97 and 27 pptv, respec- 
tively) and smaller than observed at other measurement locations for which $\mathrm{ClNO}_{2}$ abundances were reported. The low mixing ratios are explained through the removal of $\mathrm{O}_{3}$ by deposition and titration with NO in a shallow nocturnal surface layer. Measurements of submicron aerosol composition by ACSM showed no enhancements of particle-phase chloride, which is in contrast to locations where high $\mathrm{ClNO}_{2}$ mixing ratios were observed (such as Pasadena; Mielke et al., 2013) and indicates that there was little processing and redistribution of sea-salt-derived chloride at this location. There is indirect evidence that higher production of $\mathrm{ClNO}_{2}$ took place above the measurement site in the NRL, observed via down-mixing after the breakup of the NBL in the morning, and highlights the need for future vertically resolved measurements (e.g., from an aircraft platform) of $\mathrm{ClNO}_{2}$ and $\mathrm{N}_{2} \mathrm{O}_{5}$ mixing ratios in the LFV. Conditions leading to $\mathrm{O}_{3}$ exceedances did not develop during the relatively short measurement period of 2 weeks, such that the full impact that nocturnal formation of $\mathrm{ClNO}_{2}$ could have on radical production and $\mathrm{NO}_{2}$ recycling remains unquantified.

Data availability. The data used in this study are available from the corresponding author upon request (hosthoff@ucalgary.ca).

Supplement. The supplement related to this article is available online at: https://doi.org/10.5194/acp-18-6293-2018-supplement.

Competing interests. The authors declare that they have no conflict of interest.

Acknowledgements. This project was undertaken with the financial support of the Government of Canada through the Federal Department of the Environment. Partial funding for this work was provided by the Natural Sciences and Engineering Research Council of Canada (NSERC) in the form of operating ("Discovery") and Research Tools and Instruments (RTI) grants. The Abbotsford field study was financially supported by a BC Clear research grant from the Fraser Basin Council of British Columbia and by Metro Vancouver.

The authors acknowledge support by the Open Access Authors Fund at the University of Calgary and the NOAA Air Resources Laboratory (ARL) for the provision of the HYSPLIT transport and dispersion model and/or READY website (http://www.ready.noaa.gov) used in this publication.

Edited by: Timothy Bertram

Reviewed by: three anonymous referees

\section{References}

Ainslie, B. and Steyn, D. G.: Spatiotemporal Trends in Episodic Ozone Pollution in the Lower Fraser Valley, British Columbia, in Relation to Mesoscale Atmospheric Circulation Patterns and Emissions, J. Appl. Met. Climatol., 46, 1631-1644, https://doi.org/10.1175/JAM2547.1, 2007.

Ainslie, B., Steyn, D. G., Reuten, C., and Jackson, P. L.: A Retrospective Analysis of Ozone Formation in the Lower Fraser Valley, British Columbia, Canada. Part II: Influence of Emissions Reductions on Ozone Formation, Atmos.-Ocean, 51, 170-186, https://doi.org/10.1080/07055900.2013.782264, 2013.

Aldener, M., Brown, S. S., Stark, H., Williams, E. J., Lerner, B. M., Kuster, W. C., Goldan, P. D., Quinn, P. K., Bates, T. S., Fehsenfeld, F. C., and Ravishankara, A. R.: Reactivity and loss mechanisms of $\mathrm{NO}_{3}$ and $\mathrm{N}_{2} \mathrm{O}_{5}$ in a polluted marine environment: Results from in situ measurements during New England Air Quality Study 2002, J. Geophys. Res., 111, D23S73, https://doi.org/10.1029/2006JD007252, 2006.

Alfarra, M. R., Coe, H., Allan, J. D., Bower, K. N., Boudries, H., Canagaratna, M. R., Jimenez, J. L., Jayne, J. T., Garforth, A. A., Li, S.-M., and Worsnop, D. R.: Characterization of urban and rural organic particulate in the Lower Fraser Valley using two Aerodyne Aerosol Mass Spectrometers, Atmos. Environ., 38, 5745-5758, https://doi.org/10.1016/j.atmosenv.2004.01.054, 2004.

Alicke, B., Geyer, A., Hofzumahaus, A., Holland, F., Konrad, S., Patz, H. W., Schafer, J., Stutz, J., Volz-Thomas, A., and Platt, U.: OH formation by HONO photolysis during the BERLIOZ experiment, J. Geophys. Res., 108, 8247, https://doi.org/10.1029/2001JD000579, 2003.

Anlauf, K., Li, S.-M., Leaitch, R., Brook, J., Hayden, K., Toom-Sauntry, D., and Wiebe, A.: Ionic composition and size characteristics of particles in the Lower Fraser Valley: Pacific 2001 field study, Atmos. Environ., 40, 2662-2675, https://doi.org/10.1016/j.atmosenv.2005.12.027, 2006.

Bannan, T. J., Booth, A. M., Bacak, A., Muller, J. B. A., Leather, K. E., Le Breton, M., Jones, B., Young, D., Coe, H., Allan, J., Visser, S., Slowik, J. G., Furger, M., Prévôt, A. S. H., Lee, J., Dunmore, R. E., Hopkins, J. R., Hamilton, J. F., Lewis, A. C., Whalley, L. K., Sharp, T., Stone, D., Heard, D. E., Fleming, Z. L., Leigh, R., Shallcross, D. E., and Percival, C. J.: The first UK measurements of nitryl chloride using a chemical ionization mass spectrometer in central London in the summer of 2012, and an investigation of the role of $\mathrm{Cl}$ atom oxidation, J. Geophys. Res., 120, 5638-5657, https://doi.org/10.1002/2014jd022629, 2015.

Bart, M., Williams, D. E., Ainslie, B., McKendry, I., Salmond, J., Grange, S. K., Alavi-Shoshtari, M., Steyn, D., and Henshaw, G. S.: High Density Ozone Monitoring Using Gas Sensitive Semi-Conductor Sensors in the Lower Fraser Valley, British Columbia, Environ. Sci. Technol., 48, 3970-3977, https://doi.org/10.1021/es404610t, 2014.

Behnke, W., George, C., Scheer, V., and Zetzsch, C.: Production and decay of $\mathrm{ClNO}_{2}$, from the reaction of gaseous $\mathrm{N}_{2} \mathrm{O}_{5}$ with $\mathrm{NaCl}$ solution: Bulk and aerosol experiments, J. Geophys. Res., 102, 3795-3804, https://doi.org/10.1029/96JD03057 1997.

Bertram, T. H. and Thornton, J. A.: Toward a general parameterization of $\mathrm{N}_{2} \mathrm{O}_{5}$ reactivity on aqueous particles: the competing effects of particle liquid water, nitrate and chloride, Atmos. Chem. 
Phys., 9, 8351-8363, https://doi.org/10.5194/acp-9-8351-2009, 2009.

Biesenthal, T. A., Wu, Q., Shepson, P. B., Wiebe, H. A., Anlauf, K. G., and Mackay, G. I.: A study of relationships between isoprene, its oxidation products, and ozone, in the Lower Fraser Valley, BC, Atmos. Environ., 31, 2049-2058, https://doi.org/10.1016/S1352-2310(96)00318-4, 1997.

Boudries, H., Canagaratna, M. R., Jayne, J. T., Alfarra, M. R., Allan, J., Bower, K. N., Coe, H., Pryor, S. C., Jimenez, J. L., Brook, J. R., Li, S., and Worsnop, D. R.: Chemical and physical processes controlling the distribution of aerosols in the Lower Fraser Valley, Canada, during the Pacific 2001 field campaign, Atmos. Environ., 38, 5759-5774, https://doi.org/10.1016/j.atmosenv.2004.01.057, 2004.

Brook, J. R., Strawbridge, K. B., Snyder, B. J., Boudries, H., Worsnop, D., Sharma, S., Anlauf, K., Lu, G., and Hayden, K.: Towards an understanding of the fine particle variations in the LFV: integration of chemical, physical and meteorological observations, Atmos. Environ., 38, 5775-5788, https://doi.org/10.1016/j.atmosenv.2004.01.056, 2004.

Brown, S. S., Stark, H., Ciciora, S. J., and Ravishankara, A. R.: In-situ measurement of atmospheric $\mathrm{NO}_{3}$ and $\mathrm{N}_{2} \mathrm{O}_{5}$ via cavity ring-down spectroscopy, Geophys. Res. Lett., 28, 3227-3230, https://doi.org/10.1029/2001GL013303, 2001.

Brown, S. S., Stark, H., Ciciora, S. J., McLaughlin, R. J., and Ravishankara, A. R.: Simultaneous in situ detection of atmospheric $\mathrm{NO}_{3}$ and $\mathrm{N}_{2} \mathrm{O}_{5}$ via cavity ring-down spectroscopy, Rev. Sci. Instrum., 73, 3291-3301, https://doi.org/10.1063/1.1499214, 2002.

Brown, S. S., Stark, H., and Ravishankara, A. R.: Applicability of the steady state approximation to the interpretation of atmospheric observations of $\mathrm{NO}_{3}$ and $\mathrm{N}_{2} \mathrm{O}_{5}$, J. Geophys. Res., 108, 4539, https://doi.org/10.1029/2003JD003407, 2003.

Brown, S. S., Neuman, J. A., Ryerson, T. B., Trainer, M., Dube, W. P., Holloway, J. S., Warneke, C., de Gouw, J. A., Donnelly, S. G., Atlas, E., Matthew, B., Middlebrook, A. M., Peltier, R., Weber, R. J., Stohl, A., Meagher, J. F., Fehsenfeld, F. C., and Ravishankara, A. R.: Nocturnal odd-oxygen budget and its implications for ozone loss in the lower troposphere, Geophys. Res. Lett., 33, L08801, https://doi.org/10.1029/2006GL025900, 2006a.

Brown, S. S., Ryerson, T. B., Wollny, A. G., Brock, C. A., Peltier, R., Sullivan, A. P., Weber, R. J., Dube, W. P., Trainer, M., Meagher, J. F., Fehsenfeld, F. C., and Ravishankara, A. R.: Variability in nocturnal nitrogen oxide processing and its role in regional air quality, Science, 311, 67-70, https://doi.org/10.1126/science.1120120 2006b.

Brown, S. S., Dube, W. P., Osthoff, H. D., Stutz, J., Ryerson, T. B., Wollny, A. G., Brock, C. A., Warneke, C., De Gouw, J. A., Atlas, E., Neuman, J. A., Holloway, J. S., Lerner, B. M., Williams, E. J., Kuster, W. C., Goldan, P. D., Angevine, W. M., Trainer, M., Fehsenfeld, F. C., and Ravishankara, A. R.: Vertical profiles in $\mathrm{NO}_{3}$ and $\mathrm{N}_{2} \mathrm{O}_{5}$ measured from an aircraft: Results from the NOAA P-3 and surface platforms during the New England Air Quality Study 2004, J. Geophys. Res., 112, D22304, https://doi.org/10.1029/2007JD008883, 2007.

Brown, S. S. and Stutz, J.: Nighttime radical observations and chemistry, Chem. Soc. Rev., 41, 6405-6447, https://doi.org/10.1039/c2cs35181a, 2012.
Brown, S. S., Thornton, J. A., Keene, W. C., Pszenny, A. A. P., Sive, B. C., Dubé, W. P., Wagner, N. L., Young, C. J., Riedel, T. P., Roberts, J. M., VandenBoer, T. C., Bahreini, R., Öztürk, F., Middlebrook, A. M., Kim, S., Hübler, G., and Wolfe, D. E.: Nitrogen, Aerosol Composition, and Halogens on a Tall Tower (NACHTT): Overview of a wintertime air chemistry field study in the front range urban corridor of Colorado, J. Geophys. Res., 118, 8067-8085, https://doi.org/10.1002/jgrd.50537, 2013.

Brown, S. S., Dubé, W. P., Tham, Y. J., Zha, Q., Xue, L., Poon, S., Wang, Z., Blake, D. R., Tsui, W., Parrish, D. D., and Wang, T.: Nighttime chemistry at a high altitude site above Hong Kong, J. Geophys. Res.-Atmos., 121, 2457-2475, https://doi.org/10.1002/2015jd024566, 2016.

Chang, W. L., Bhave, P. V., Brown, S. S., Riemer, N., Stutz, J., and Dabdub, D.: Heterogeneous Atmospheric Chemistry, Ambient Measurements, and Model Calculations of $\mathrm{N}_{2} \mathrm{O}_{5}$ : A Review, Aerosol Sci. Technol., 45, 655-685, https://doi.org/10.1080/02786826.2010.551672, 2011.

Crowley, J. N., Schuster, G., Pouvesle, N., Parchatka, U., Fischer, H., Bonn, B., Bingemer, H., and Lelieveld, J.: Nocturnal nitrogen oxides at a rural mountain-site in south-western Germany, Atmos. Chem. Phys., 10, 2795-2812, https://doi.org/10.5194/acp10-2795-2010, 2010.

Curren, K. C., Dann, T. F., and Wang, D. K.: Ambient air 1,3-butadiene concentrations in Canada (19952003): seasonal, day of week variations, trends, and source influences, Atmos. Environ., 40, 170-181, https://doi.org/10.1016/j.atmosenv.2005.09.025, 2006.

Davidovits, P., Kolb, C. E., Williams, L. R., Jayne, J. T., and Worsnop, D. R.: Mass accommodation and chemical reactions at gas-liquid interfaces, Chem. Rev., 106, 1323-1354, 2006.

Drewitt, G. B., Curren, K., Steyn, D. G., Gillespie, T. J., and Niki, H.: Measurement of biogenic hydrocarbon emissions from vegetation in the Lower Fraser Valley, British Columbia, Atmos. Environ., 32, 3457-3466, https://doi.org/10.1016/S13522310(98)00043-0, 1998.

Dubé, W. P., Brown, S. S., Osthoff, H. D., Nunley, M. R., Ciciora, S. J., Paris, M. W., McLaughlin, R. J., and Ravishankara, A. R.: Aircraft instrument for simultaneous, in situ measurement of $\mathrm{NO}_{3}$ and $\mathrm{N}_{2} \mathrm{O}_{5}$ via pulsed cavity ring-down spectroscopy, Rev. Sci. Instrum., 77, 034101, https://doi.org/10.1063/1.2176058, 2006.

Edwards, P. M., Brown, S. S., Roberts, J. M., Ahmadov, R., Banta, R. M., deGouw, J. A., Dube, W. P., Field, R. A., Flynn, J. H., Gilman, J. B., Graus, M., Helmig, D., Koss, A., Langford, A. O., Lefer, B. L., Lerner, B. M., Li, R., Li, S.-M., McKeen, S. A., Murphy, S. M., Parrish, D. D., Senff, C. J., Soltis, J., Stutz, J., Sweeney, C., Thompson, C. R., Trainer, M. K., Tsai, C., Veres, P. R., Washenfelder, R. A., Warneke, C., Wild, R. J., Young, C. J., Yuan, B., and Zamora, R.: High winter ozone pollution from carbonyl photolysis in an oil and gas basin, Nature, 514, 351354, https://doi.org/10.1038/nature13767, 2014.

Faxon, C., Bean, J., and Ruiz, L.: Inland Concentrations of $\mathrm{Cl}_{2}$ and $\mathrm{ClNO}_{2}$ in Southeast Texas Suggest Chlorine Chemistry Significantly Contributes to Atmospheric Reactivity, Atmosphere, 6, 1487-1506, https://doi.org/10.3390/atmos6101487, 2015.

Finlayson-Pitts, B. J., Ezell, M. J., and Pitts, J. N.: Formation Of Chemically Active Chlorine Compounds By Reactions Of Atmospheric $\mathrm{NaCl}$ Particles With Gaseous $\mathrm{N}_{2} \mathrm{O}_{5}$ And $\mathrm{ClONO}_{2}$, Nature, 337, 241-244, https://doi.org/10.1038/337241a0 1989. 
Geyer, A. and Stutz, J.: Vertical profiles of $\mathrm{NO}_{3}, \mathrm{~N}_{2} \mathrm{O}_{5}, \mathrm{O}_{3}$, and $\mathrm{NO}_{x}$ in the nocturnal boundary layer: 2 . Model studies on the altitude dependence of composition and chemistry, J. Geophys. Res., 109, D12307, https://doi.org/10.1029/2003JD004211, 2004.

Ghosh, B., Papanastasiou, D. K., Talukdar, R. K., Roberts, J. M., and Burkholder, J. B.: Nitryl Chloride $\left(\mathrm{ClNO}_{2}\right)$ : UV/Vis $\mathrm{Ab}-$ sorption Spectrum between 210 and $296 \mathrm{~K}$ and $\mathrm{O}\left({ }^{3} \mathrm{P}\right)$ Quantum Yield at 193 and $248 \mathrm{~nm}$, J. Phys. Chem. A, 116, 5796-5805, https://doi.org/10.1021/jp207389y, 2012.

Guenther, A., Hewitt, C. N., Erickson, D., Fall, R., Geron, C., Graedel, T., Harley, P., Klinger, L., Lerdau, M., McKay, W. A., Pierce, T., Scholes, B., Steinbrecher, R., Tallamraju, R., Taylor, J., and Zimmerman, P.: A Global-Model Of Natural Volatile Organic-Compound Emissions, J. Geophys. Res., 100, 88738892, https://doi.org/10.1029/94JD02950, 1995.

Guenther, A. B., Jiang, X., Heald, C. L., Sakulyanontvittaya, T., Duhl, T., Emmons, L. K., and Wang, X.: The Model of Emissions of Gases and Aerosols from Nature version 2.1 (MEGAN2.1): an extended and updated framework for modeling biogenic emissions, Geosci. Model Dev., 5, 1471-1492, https://doi.org/10.5194/gmd-5-1471-2012, 2012.

Gurren, K., Gillespie, T., Steyn, D., Dann, T., and Wang, D.: Biogenic isoprene in the Lower Fraser Valley, British Columbia, J. Geophys. Res.-Atmos., 103, 25467-25477, https://doi.org/10.1029/98jd01214, 1998.

Hannemann, A. U., Mitra, S. K., and Pruppacher, H. R.: On the scavenging of gaseous nitrogen compounds by large and small rain drops 1. A wind tunnel and theoretical study of the uptake and desorption of $\mathrm{NH}_{3}$ in the presence of $\mathrm{CO}_{2}$, J. Atmos. Chem., 21, 293-307, https://doi.org/10.1007/bf00696760, 1995.

Hayden, K. L., Anlauf, K. G., Hoff, R. M., Strapp, J. W., Bottenheim, J. W., Wiebe, H. A., Froude, F. A., Martin, J. B., Steyn, D. G., and McKendry, I. G.: The vertical chemical and meteorological structure of the boundary layer in the Lower Fraser Valley during Pacific '93, Atmos. Environ., 31, 20892105, https://doi.org/10.1016/S1352-2310(96)00300-7, 1997.

Hayden, K. L., Anlauf, K. G., Li, S. M., Macdonald, A. M., Bottenheim, J. W., Brook, J. R., and Wiebe, H. A.: Characterization of gaseous nitrogen oxides in the Lower Fraser Valley during Pacific 2001, Atmos. Environ., 38, 5811-5823, https://doi.org/10.1016/j.atmosenv.2003.12.048, 2004.

Heintz, F., Platt, U., Flentje, H., and Dubois, R.: Longterm observation of nitrate radicals at the Tor station, Kap Arkona (Rugen), J. Geophys. Res., 101, 22891-22910, https://doi.org/10.1029/96JD01549, 1996.

Hewitt, C. N., Ashworth, K., Boynard, A., Guenther, A., Langford, B., MacKenzie, A. R., Misztal, P. K., Nemitz, E., Owen, S. M., Possell, M., Pugh, T. A. M., Ryan, A. C., and Wild, O.: Ground-level ozone influenced by circadian control of isoprene emissions, Nat. Geosci., 4, 671-674, https://doi.org/10.1038/ngeo1271, 2011.

Hofzumahaus, A., Kraus, A., and Muller, M.: Solar actinic flux spectroradiometry: a technique for measuring photolysis frequencies in the atmosphere, Appl. Opt., 38, 4443-4460, https://doi.org/10.1364/AO.38.004443, 1999.

Indarto, A.: Heterogeneous reactions of HONO formation from $\mathrm{NO}_{2}$ and $\mathrm{HNO}_{3}$ : a review, Res. Chem. Intermed., 38, 10291041, https://doi.org/10.1007/s11164-011-0439-z, 2012.
Jimenez, J. L., Canagaratna, M. R., Donahue, N. M., Prevot, A. S. H., Zhang, Q., Kroll, J. H., DeCarlo, P. F., Allan, J. D., Coe, H., Ng, N. L., Aiken, A. C., Docherty, K. S., Ulbrich, I. M., Grieshop, A. P., Robinson, A. L., Duplissy, J., Smith, J. D., Wilson, K. R., Lanz, V. A., Hueglin, C., Sun, Y. L., Tian, J., Laaksonen, A., Raatikainen, T., Rautiainen, J., Vaattovaara, P., Ehn, M., Kulmala, M., Tomlinson, J. M., Collins, D. R., Cubison, M. J., E., Dunlea, J., Huffman, J. A., Onasch, T. B., Alfarra, M. R., Williams, P. I., Bower, K., Kondo, Y., Schneider, J., Drewnick, F., Borrmann, S., Weimer, S., Demerjian, K., Salcedo, D., Cottrell, L., Griffin, R., Takami, A., Miyoshi, T., Hatakeyama, S., Shimono, A., Sun, J. Y., Zhang, Y. M., Dzepina, K., Kimmel, J. R., Sueper, D., Jayne, J. T., Herndon, S. C., Trimborn, A. M., Williams, L. R., Wood, E. C., Middlebrook, A. M., Kolb, C. E., Baltensperger, U., and Worsnop, D. R.: Evolution of Organic Aerosols in the Atmosphere, Science, 326, 1525-1529, https://doi.org/10.1126/science.1180353, 2009.

Kercher, J. P., Riedel, T. P., and Thornton, J. A.: Chlorine activation by $\mathrm{N}_{2} \mathrm{O}_{5}$ : simultaneous, in situ detection of $\mathrm{ClNO}_{2}$ and $\mathrm{N}_{2} \mathrm{O}_{5}$ by chemical ionization mass spectrometry, Atmos. Meas. Tech., 2, 193-204, https://doi.org/10.5194/amt-2-193-2009, 2009.

Kim, M. J., Farmer, D. K., and Bertram, T. H.: A controlling role for the air-sea interface in the chemical processing of reactive nitrogen in the coastal marine boundary layer, Proc. Natl. Acad. Sci. USA, 111, 3943-3948, https://doi.org/10.1073/pnas.1318694111, 2014.

Kleinman, L., Lee, Y.-N., Springston, S. R., Nunnermacker, L., Zhou, X., Brown, R., Hallock, K., Klotz, P., Leahy, D., Lee, J. H., and Newman, L.: Ozone formation at a rural site in the southeastern United States, J. Geophys. Res.-Atmos., 99, 3469-3482, https://doi.org/10.1029/93jd02991, 1994.

Knipping, E. M. and Dabdub, D.: Impact of chlorine emissions from sea-salt aerosol on coastal urban ozone, Environ. Sci. Technol., 37, 275-284, https://doi.org/10.1021/es025793z 2003.

Koehler, G. and Wassenaar, L. I.: The stable isotopic composition $\left({ }^{37} \mathrm{Cl} /{ }^{35} \mathrm{Cl}\right)$ of dissolved chloride in rainwater, Appl. Geochem., 25, 91-96, https://doi.org/10.1016/j.apgeochem.2009.10.004, 2010.

Liebmann, J., Karu, E., Sobanski, N., Schuladen, J., Ehn, M., Schallhart, S., Quéléver, L., Hellen, H., Hakola, H., Hoffmann, T., Williams, J., Fischer, H., Lelieveld, J., and Crowley, J. N.: Direct measurement of $\mathrm{NO}_{3}$ radical reactivity in a boreal forest, Atmos. Chem. Phys., 18, 3799-3815, https://doi.org/10.5194/acp18-3799-2018, 2018.

Lin, C. H., Lai, C. H., Wu, Y. L., and Chen, M. J.: Simple model for estimating dry deposition velocity of ozone and its destruction in a polluted nocturnal boundary layer, Atmos. Environ., 44, 4364 4371, https://doi.org/10.1016/j.atmosenv.2010.07.053, 2010.

Logan, J. A.: Ozone in rural areas of the United States, J. Geophys. Res.-Atmos., 94, 8511-8532, https://doi.org/10.1029/JD094iD06p08511, 1989.

Madronich, S. and Flocke, S.: Theoretical Estimation of Biologically Effective UV Radiation at the Earth's Surface, in: Solar Ultraviolet Radiation, edited by: Zerefos, C. and Bais, A., NATO ASI Series, Springer Berlin Heidelberg, 23-48, 1997.

McKendry, I. G., Steyn, D. G., Lundgren, J., Hoff, R. M., Strapp, W., Anlauf, K., Froude, F., Martin, J. B., Banta, R. M., and Olivier, L. D.: Elevated ozone layers and vertical down-mixing 
over the Lower Fraser Valley, BC, Atmos. Environ., 31, 21352146, https://doi.org/10.1016/S1352-2310(96)00127-6, 1997.

McLaren, R., Salmon, R. A., Liggio, J., Hayden, K. L., Anlauf, K. G., and Leaitch, W. R.: Nighttime chemistry at a rural site in the Lower Fraser Valley, Atmos. Environ., 38, 5837-5848, https://doi.org/10.1016/j.atmosenv.2004.03.074, 2004.

McLaren, R., Wojtal, P., Majonis, D., McCourt, J., Halla, J. D., and Brook, J.: $\mathrm{NO}_{3}$ radical measurements in a polluted marine environment: links to ozone formation, Atmos. Chem. Phys., 10, 4187-4206, https://doi.org/10.5194/acp-10-4187-2010, 2010.

Mielke, L. H., Furgeson, A., and Osthoff, H. D.: Observation of $\mathrm{ClNO}_{2}$ in a mid-continental urban environment, Environ. Sci. Technol., 45, 8889-8896, https://doi.org/10.1021/es201955u, 2011.

Mielke, L. H. and Osthoff, H. D.: On quantitative measurements of peroxycarboxylic nitric anhydride mixing ratios by thermal dissociation chemical ionization mass spectrometry, Int. J. Mass Spectrom., 310, 1-9, https://doi.org/10.1016/j.ijms.2011.10.005, 2012.

Mielke, L. H., Stutz, J., Tsai, C., Hurlock, S. C., Roberts, J. M., Veres, P. R., Froyd, K. D., Hayes, P. L., Cubison, M. J., Jimenez, J. L., Washenfelder, R. A., Young, C. J., Gilman, J. B., de Gouw, J. A., Flynn, J. H., Grossberg, N., Lefer, B. L., Liu, J., Weber, R. J., and Osthoff, H. D.: Heterogeneous formation of nitryl chloride and its role as a nocturnal $\mathrm{NO}_{x}$ reservoir species during CalNex-LA 2010, J. Geophys. Res., 118, 10638-10652, https://doi.org/10.1002/jgrd.50783, 2013.

Mielke, L. H., Furgeson, A., Odame-Ankrah, C. A., and Osthoff, H. D.: Ubiquity of $\mathrm{ClNO}_{2}$ in the nocturnal boundary layer of Calgary, AB, Canada, Can. J. Chem., 94, 414-423, https://doi.org/10.1139/cjc-2015-0426, 2016.

Neu, U., Kunzle, T., and Wanner, H.: On the relation between ozone storage in the residual layer and daily variation in near-surface ozone concentration - A case study, Bound.-Layer Meteor., 69, 221-247, https://doi.org/10.1007/bf00708857, 1994.

Ng, N. L., Herndon, S. C., Trimborn, A., Canagaratna, M. R., Croteau, P. L., Onasch, T. B., Sueper, D., Worsnop, D. R., Zhang, Q., Sun, Y. L., and Jayne, J. T.: An Aerosol Chemical Speciation Monitor (ACSM) for Routine Monitoring of the Composition and Mass Concentrations of Ambient Aerosol, Aerosol Sci. Technol., 45, 780-794, https://doi.org/10.1080/02786826.2011.560211, 2011.

Odame-Ankrah, C. A. and Osthoff, H. D.: A compact diode laser cavity ring-down spectrometer for atmospheric measurements of $\mathrm{NO}_{3}$ and $\mathrm{N}_{2} \mathrm{O}_{5}$ with automated zeroing and calibration, Appl. Spectrosc., 65, 1260-1268, https://doi.org/10.1366/1106384, 2011.

Odame-Ankrah, C. A.: Improved detection instrument for nitrogen oxide species, Ph.D., Chemistry, University of Calgary, Calgary, available at: http://hdl.handle.net/11023/2006, 2015.

Osthoff, H. D., Sommariva, R., Baynard, T., Pettersson, A., Williams, E. J., Lerner, B. M., Roberts, J. M., Stark, H., Goldan, P. D., Kuster, W. C., Bates, T. S., Coffman, D., Ravishankara, A. R., and Brown, S. S.: Observation of daytime $\mathrm{N}_{2} \mathrm{O}_{5}$ in the marine boundary layer during New England Air Quality Study - Intercontinental Transport and Chemical Transformation 2004, J. Geophys. Res., 111, D23S14, https://doi.org/10.1029/2006JD007593., 2006.
Osthoff, H. D., Pilling, M. J., Ravishankara, A. R., and Brown, S. S.: Temperature dependence of the $\mathrm{NO}_{3}$ absorption crosssection above $298 \mathrm{~K}$ and determination of the equilibrium constant for $\mathrm{NO}_{3}+\mathrm{NO}_{2}<->\mathrm{N}_{2} \mathrm{O}_{5}$ at atmospherically relevant conditions, Phys. Chem. Chem. Phys., 9, 5785-5793, https://doi.org/10.1039/b709193a, 2007.

Osthoff, H. D., Roberts, J. M., Ravishankara, A. R., Williams, E. J., Lerner, B. M., Sommariva, R., Bates, T. S., Coffman, D., Quinn, P. K., Stark, H., Burkholder, J. B., Talukdar, R. K., Meagher, J., Fehsenfeld, F. C., and Brown, S. S.: High levels of nitryl chloride in the polluted subtropical marine boundary layer, Nat. Geosci., 1, 324-328, https://doi.org/10.1038/ngeo177, 2008.

Paul, D., Furgeson, A., and Osthoff, H. D.: Measurement of total alkyl and peroxy nitrates by thermal decomposition cavity ring-down spectroscopy, Rev. Sci. Instrum., 80, 114101, https://doi.org/10.1063/1.3258204 2009.

Paul, D. and Osthoff, H. D.: Absolute Measurements of Total Peroxy Nitrate Mixing Ratios by Thermal Dissociation Blue Diode Laser Cavity Ring-Down Spectroscopy, Anal. Chem., 82, 66956703, https://doi.org/10.1021/ac101441z, 2010.

Phillips, G. J., Tang, M. J., Thieser, J., Brickwedde, B., Schuster, G., Bohn, B., Lelieveld, J., and Crowley, J. N.: Significant concentrations of nitryl chloride observed in rural continental Europe associated with the influence of sea salt chloride and anthropogenic emissions, Geophys. Res. Lett., 39, L10811, https://doi.org/10.1029/2012gl051912, 2012.

Phillips, G. J., Thieser, J., Tang, M., Sobanski, N., Schuster, G., Fachinger, J., Drewnick, F., Borrmann, S., Bingemer, H., Lelieveld, J., and Crowley, J. N.: Estimating $\mathrm{N}_{2} \mathrm{O}_{5}$ uptake coefficients using ambient measurements of $\mathrm{NO}_{3}, \mathrm{~N}_{2} \mathrm{O}_{5}, \mathrm{ClNO}_{2}$ and particle-phase nitrate, Atmos. Chem. Phys., 16, 13231-13249, https://doi.org/10.5194/acp-16-13231-2016, 2016.

Pisano, J. T., McKendry, I., Steyn, D. G., and Hastie, D. R.: Vertical nitrogen dioxide and ozone concentrations measured from a tethered balloon in the Lower Fraser Valley, Atmos. Environ., 31, 2071-2078, https://doi.org/10.1016/S1352-2310(96)00146X, 1997.

Pryor, S. C., Barthelmie, R. J., Hoff, R. M., Sakiyama, S., Simpson, R., and Steyn, D.: REVEAL: Characterizing fine aerosols in the Fraser Valley, BC, Atmos.-Ocean, 35, 209-227, https://doi.org/10.1080/07055900.1997.9649592, 1997.

Pryor, S. C. and Barthelmie, R. J.: REVEAL II: Seasonality and spatial variability of particle and visibility conditions in the Fraser Valley, Sci. Total Environ., 257, 95-110, https://doi.org/10.1016/S0048-9697(00)00490-3, 2000.

Pryor, S. C., Barthelmie, R. J., Schoof, J. T., Binkowski, F. S., Delle Monache, L., and Stull, R.: Modeling the impact of sea-spray on particle concentrations in a coastal city, Sci. Total Environ., 391, 132-142, https://doi.org/10.1016/j.scitotenv.2007.10.059, 2008.

Raff, J. D., Njegic, B., Chang, W. L., Gordon, M. S., Dabdub, D., Gerber, R. B., and Finlayson-Pitts, B. J.: Chlorine activation indoors and outdoors via surface-mediated reactions of nitrogen oxides with hydrogen chloride, Proc. Natl. Acad. Sci. USA, 106, 13647-13654, https://doi.org/10.1073/pnas.0904195106, 2009.

Riedel, T. P., Bertram, T. H., Crisp, T. A., Williams, E. J., Lerner, B. M., Vlasenko, A., Li, S.-M., Gilman, J. B., de Gouw, J., Bon, D. M., Wagner, N. L., Brown, S. S., and Thornton, J. A.: Nitryl Chloride and Molecular Chlorine in the Coastal Ma- 
rine Boundary Layer, Environ. Sci. Technol., 46, 10463-10470, https://doi.org/10.1021/es204632r, 2012a.

Riedel, T. P., Bertram, T. H., Ryder, O. S., Liu, S., Day, D. A., Russell, L. M., Gaston, C. J., Prather, K. A., and Thornton, J. A.: Direct $\mathrm{N}_{2} \mathrm{O}_{5}$ reactivity measurements at a polluted coastal site, Atmos. Chem. Phys., 12, 2959-2968, https://doi.org/10.5194/acp12-2959-2012, 2012b.

Riedel, T. P., Wagner, N. L., Dubé, W. P., Middlebrook, A. M., Young, C. J., Öztürk, F., Bahreini, R., VandenBoer, T. C., Wolfe, D. E., Williams, E. J., Roberts, J. M., Brown, S. S., and Thornton, J. A.: Chlorine activation within urban or power plant plumes: Vertically resolved $\mathrm{ClNO}_{2}$ and $\mathrm{Cl}_{2}$ measurements from a tall tower in a polluted continental setting, J. Geophys. Res., 118, 8702-8715, https://doi.org/10.1002/jgrd.50637, 2013.

Roberts, J. M., Osthoff, H. D., Brown, S. S., Ravishankara, A. R., Coffman, D., Quinn, P. K., and Bates, T. S.: Laboratory Studies of Products of $\mathrm{N}_{2} \mathrm{O}_{5}$ Uptake on $\mathrm{Cl}^{-}$ Containing Substrates, Geophys. Res. Lett., 36, L20808, https://doi.org/10.1029/2009GL040448, 2009.

Ryder, O. S., Ault, A. P., Cahill, J. F., Guasco, T. L., Riedel, T. P., Cuadra-Rodriguez, L. A., Gaston, C. J., Fitzgerald, E., Lee, C., Prather, K. A., and Bertram, T. H.: On the Role of Particle Inorganic Mixing State in the Reactive Uptake of $\mathrm{N}_{2} \mathrm{O}_{5}$ to Ambient Aerosol Particles, Environ. Sci. Technol., 48, 1618-1627, https://doi.org/10.1021/es4042622, 2014.

Ryder, O. S., Campbell, N. R., Morris, H., Forestieri, S., Ruppel, M. J., Cappa, C., Tivanski, A., Prather, K., and Bertram, T. H.: Role of Organic Coatings in Regulating $\mathrm{N}_{2} \mathrm{O}_{5}$ Reactive Uptake to Sea Spray Aerosol, J. Phys. Chem. A, 119, 11683-11692, https://doi.org/10.1021/acs.jpca.5b08892, 2015.

Sander, R. and Crutzen, P. J.: Model study indicating halogen activation and ozone destruction in polluted air masses transported to the sea, J. Geophys. Res., 101, 9121-9138, https://doi.org/10.1029/95JD03793, 1996.

Sander, S. P., Abbatt, J. P. D., Barker, J. R., Burkholder, J. B., Friedl, R. R., Golden, D. M., Huie, R. E., Kolb, C. E., Kurylo, M. J., Moortgat, G. K., Orkin, V. L., and Wine, P. H.: Chemical Kinetics and Photochemical Data for Use in Atmospheric Studies, Evaluation No. 17, JPL Publication 10-6, Jet Propulsion Laboratory, Pasadena, CA, 2010.

Sarwar, G., Simon, H., Xing, J., and Mathur, R.: Importance of tropospheric $\mathrm{ClNO}_{2}$ chemistry across the Northern Hemisphere, Geophys. Res. Lett., 41, 4050-4058, https://doi.org/10.1002/2014gl059962, 2014.

Seinfeld, J. H. and Pandis, S. N.: Atmospheric chemistry and physics: from air pollution to climate change, 2nd Ed., Wiley, Hoboken, N.J., 2006.

Simpson, W. R.: Continuous wave cavity ring-down spectroscopy applied to in situ detection of dinitrogen pentoxide $\left(\mathrm{N}_{2} \mathrm{O}_{5}\right)$, Rev. Sci. Instrum., 74, 3442-3452, https://doi.org/10.1063/1.1578705, 2003.

Slusher, D. L., Huey, L. G., Tanner, D. J., Flocke, F. M., and Roberts, J. M.: A thermal dissociation-chemical ionization mass spectrometry (TD-CIMS) technique for the simultaneous measurement of peroxyacyl nitrates and dinitrogen pentoxide, J. Geophys. Res., 109, D19315, https://doi.org/10.1029/2004JD004670, 2004.

Stein, A. F., Draxler, R. R., Rolph, G. D., Stunder, B. J. B., Cohen, M. D., and Ngan, F.: NOAA's HYSPLIT atmospheric trans- port and dispersion modeling system, B. Am. Meteorol. Soc., 96, 2059-2077, https://doi.org/10.1175/bams-d-14-00110.1, 2015.

Steyn, D. G., Bottenheim, J. W., and Thomson, R. B.: Overview of tropospheric ozone in the Lower Fraser Valley, and the Pacific '93 field study, Atmos. Environ., 31, 2025-2035, https://doi.org/10.1016/S1352-2310(97)00018-6, 1997.

Stutz, J., Alicke, B., Ackermann, R., Geyer, A., Wang, S. H., White, A. B., Williams, E. J., Spicer, C. W., and Fast, J. D.: Relative humidity dependence of HONO chemistry in urban areas, J. Geophys. Res., 109, D03307, https://doi.org/10.1029/2003JD004135, 2004a.

Stutz, J., Alicke, B., Ackermann, R., Geyer, A., White, A., and Williams, E.: Vertical profiles of $\mathrm{NO}_{3}, \mathrm{~N}_{2} \mathrm{O}_{5}, \mathrm{O}_{3}$, and $\mathrm{NO}_{x}$ in the nocturnal boundary layer: 1 . Observations during the Texas Air Quality Study 2000, J. Geophys. Res., 109, D12306, https://doi.org/10.1029/2003JD004209, 2004b.

Talbot, R., Mao, H. T., and Sive, B.: Diurnal characteristics of surface level $\mathrm{O}_{3}$ and other important trace gases in New England, J. Geophys. Res., 110, D09307, https://doi.org/10.1029/2004JD005449, 2005.

Tanaka, P. L., Riemer, D. D., Chang, S. H., Yarwood, G., McDonald-Buller, E. C., Apel, E. C., Orlando, J. J., Silva, P. J., Jimenez, J. L., Canagaratna, M. R., Neece, J. D., Mullins, C. B., and Allen, D. T.: Direct evidence for chlorine-enhanced urban ozone formation in Houston, Texas, Atmos. Environ., 37, 1393 1400, https://doi.org/10.1016/S1352-2310(02)01007-5 2003.

Thaler, R. D., Mielke, L. H., and Osthoff, H. D.: Quantification of Nitryl Chloride at Part Per Trillion Mixing Ratios by Thermal Dissociation Cavity Ring-Down Spectroscopy, Anal. Chem., 83, 2761-2766, https://doi.org/10.1021/ac200055z, 2011.

Tham, Y., Yan, C., Xue, L., Zha, Q., Wang, X., and Wang, T.: Presence of high nitryl chloride in Asian coastal environment and its impact on atmospheric photochemistry, Chin. Sci. Bull., 59, 356-359, https://doi.org/10.1007/s11434-013-0063-y, 2014.

Tham, Y. J., Wang, Z., Li, Q., Yun, H., Wang, W., Wang, X., Xue, L., Lu, K., Ma, N., Bohn, B., Li, X., Kecorius, S., Größ, J., Shao, M., Wiedensohler, A., Zhang, Y., and Wang, T.: Significant concentrations of nitryl chloride sustained in the morning: investigations of the causes and impacts on ozone production in a polluted region of northern China, Atmos. Chem. Phys., 16, 14959-14977, https://doi.org/10.5194/acp-16-14959-2016, 2016.

Thieser, J., Schuster, G., Schuladen, J., Phillips, G. J., Reiffs, A., Parchatka, U., Pöhler, D., Lelieveld, J., and Crowley, J. N.: A two-channel thermal dissociation cavity ring-down spectrometer for the detection of ambient $\mathrm{NO}_{2}, \mathrm{RO}_{2} \mathrm{NO}_{2}$ and $\mathrm{RONO}_{2}$, Atmos. Meas. Tech., 9, 553-576, https://doi.org/10.5194/amt-9553-2016, 2016.

Thornton, J. A., Kercher, J. P., Riedel, T. P., Wagner, N. L., Cozic, J., Holloway, J. S., Dube, W. P., Wolfe, G. M., Quinn, P. K., Middlebrook, A. M., Alexander, B., and Brown, S. S.: A large atomic chlorine source inferred from midcontinental reactive nitrogen chemistry, Nature, 464, 271-274, https://doi.org/10.1038/nature08905, 2010.

Tokarek, T. W., Huo, J. A., Odame-Ankrah, C. A., Hammoud, D., Taha, Y. M., and Osthoff, H. D.: A gas chromatograph for quantification of peroxycarboxylic nitric anhydrides calibrated by thermal dissociation cavity ring-down spectroscopy, Atmos. Meas. Tech., 7, 3263-3283, https://doi.org/10.5194/amt-7-32632014, 2014. 
Trainer, M., Williams, E. J., Parrish, D. D., Buhr, M. P., Allwine, E. J., Westberg, H. H., Fehsenfeld, F. C., and Liu, S. C.: Models and observations of the impact of natural hydrocarbons on rural ozone, Nature, 329, 705-707, https://doi.org/10.1038/329705a0, 1987.

Tsai, C., Wong, C., Hurlock, S., Pikelnaya, O., Mielke, L. H., Osthoff, H. D., Flynn, J. H., Haman, C., Lefer, B., Gilman, J., de Gouw, J., and Stutz, J.: Nocturnal loss of $\mathrm{NO}_{x}$ during the 2010 CalNex-LA study in the Los Angeles Basin, J. Geophys. Res., 119, 13004-13025, https://doi.org/10.1002/2014jd022171, 2014.

Vingarzan, R. and Li, S. M.: The Pacific 2001 Air Quality Study synthesis of findings and policy implications, Atmos. Environ., 40, 2637-2649, https://doi.org/10.1016/j.atmosenv.2005.09.083, 2006.

Volpe, C., Wahlen, M., Pszenny, A. A. P., and Spivack, A. J.: Chlorine isotopic composition of marine aerosols: Implications for the release of reactive chlorine and $\mathrm{HCl}$ cycling rates, Geophys. Res. Lett., 25, 3831-3834, https://doi.org/10.1029/1998gl900038, 1998.

Wagner, N. L., Dube, W. P., Washenfelder, R. A., Young, C. J., Pollack, I. B., Ryerson, T. B., and Brown, S. S.: Diode laser-based cavity ring-down instrument for $\mathrm{NO}_{3}, \mathrm{~N}_{2} \mathrm{O}_{5}, \mathrm{NO}, \mathrm{NO}_{2}$ and $\mathrm{O}_{3}$ from aircraft, Atmospheric Measurement Techniques, 4, 12271240, https://doi.org/10.5194/amt-4-1227-2011, 2011.

Wang, S., Ackermann, R., and Stutz, J.: Vertical profiles of $\mathrm{O}_{3}$ and $\mathrm{NO}_{x}$ chemistry in the polluted nocturnal boundary layer in Phoenix, AZ: I. Field observations by long-path DOAS, Atmos. Chem. Phys., 6, 2671-2693, https://doi.org/10.5194/acp-6-26712006, 2006.

Wang, T., Tham, Y. J., Xue, L., Li, Q., Zha, Q., Wang, Z., Poon, S. C. N., Dubé, W. P., Blake, D. R., Louie, P. K. K., Luk, C. W. Y., Tsui, W., and Brown, S. S.: Observations of nitryl chloride and modeling its source and effect on ozone in the planetary boundary layer of southern China, J. Geophys. Res.-Atmos., 121, 2476-2489, https://doi.org/10.1002/2015jd024556, 2016.

Wang, X., Wang, H., Xue, L., Wang, T., Wang, L., Gu, R., Wang, W., Tham, Y. J., Wang, Z., Yang, L., Chen, J., and Wang, W.: Observations of $\mathrm{N}_{2} \mathrm{O}_{5}$ and $\mathrm{ClNO}_{2}$ at a polluted urban surface site in North China: High $\mathrm{N}_{2} \mathrm{O}_{5}$ uptake coefficients and low $\mathrm{ClNO}_{2}$ product yields, Atmos. Environm., 156, 125-134, https://doi.org/10.1016/j.atmosenv.2017.02.035, 2017.
Wayne, R. P., Barnes, I., Biggs, P., Burrows, J. P., Canosamas, C. E., Hjorth, J., Lebras, G., Moortgat, G. K., Perner, D., Poulet, G., Restelli, G., and Sidebottom, H.: The Nitrate Radical - Physics, Chemistry, and the Atmosphere, Atmos. Environm. A, 25, 1203, https://doi.org/10.1016/0960-1686(91)90192-A, 1991.

Wieser, M. E. and Berglund, M.: Atomic weights of the elements 2007 (IUPAC Technical Report), Pure Appl. Chem., 81, 21312156, https://doi.org/10.1351/pac-rep-09-08-03, 2009.

Wild, R. J., Dubé, W. P., Aikin, K. C., Eilerman, S. J., Neuman, J. A., Peischl, J., Ryerson, T. B., and Brown, S. S.: On-road measurements of vehicle $\mathrm{NO}_{2} / \mathrm{NO}_{x}$ emission ratios in Denver, Colorado, USA, Atmos. Environ., 148, 182-189, https://doi.org/10.1016/j.atmosenv.2016.10.039, 2017.

Wood, E. C., Bertram, T. H., Wooldridge, P. J., and Cohen, R. C.: Measurements of $\mathrm{N}_{2} \mathrm{O}_{5}, \mathrm{NO}_{2}$, and $\mathrm{O}_{3}$ east of the San Francisco Bay, Atmos. Chem. Phys., 5, 483-491, https://doi.org/10.5194/acp-5-483-2005, 2005.

Young, C. J., Washenfelder, R. A., Roberts, J. M., Mielke, L. H., Osthoff, H. D., Tsai, C., Pikelnaya, O., Stutz, J., Veres, P. R., Cochran, A. K., VandenBoer, T. C., Flynn, J., Grossberg, N., Haman, C. L., Lefer, B., Stark, H., Graus, M., de Gouw, J., Gilman, J. B., Kuster, W. C., and Brown, S. S.: Vertically Resolved Measurements of Nighttime Radical Reservoirs in Los Angeles and Their Contribution to the Urban Radical Budget, Environ. Sci. Technol., 46, 10965-10973, https://doi.org/10.1021/es302206a, 2012.

Young, C. J., Washenfelder, R. A., Edwards, P. M., Parrish, D. D., Gilman, J. B., Kuster, W. C., Mielke, L. H., Osthoff, H. D., Tsai, C., Pikelnaya, O., Stutz, J., Veres, P. R., Roberts, J. M., Griffith, S., Dusanter, S., Stevens, P. S., Flynn, J., Grossberg, N., Lefer, B., Holloway, J. S., Peischl, J., Ryerson, T. B., Atlas, E. L., Blake, D. R., and Brown, S. S.: Chlorine as a primary radical: evaluation of methods to understand its role in initiation of oxidative cycles, Atmos. Chem. Phys., 14, 3427-3440, https://doi.org/10.5194/acp-14-3427-2014, 2014.

Zhang, Q., Jimenez, J. L., Worsnop, D. R., and Canagaratna, M.: A case study of urban particle acidity and its influence on secondary organic aerosol, Environm. Sci. Technol., 41, 3213-3219, https://doi.org/10.1021/es061812j, 2007. 